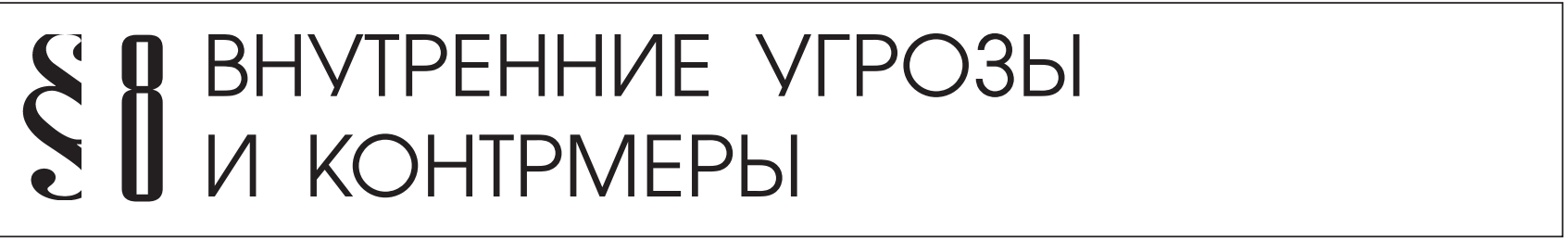

Х.В. Дзуцев, Ю.Ю. Синелина

\title{
РАСПРОСТРАНЕНИЕ РЕЛИГИОЗНОГО ТЕЧЕНИЯ ВАХХАБИЗМ В РЕСПУБЛИКАХ СЕВЕРО-КАВКАЗСКОГО ФЕДЕРАЛЬНОГО ОКРУГА РОССИЙСКОЙ ФЕДЕРАЦИИ: ЭТНОСОЦИОЛОГИЧЕСКИЙ АНАЛИЗ
}

\begin{abstract}
Аннотация: Данная статья написана по материалам этносоциологических исследований на тему: «Ваххабизм в республиках Северо-Кавказского Федерального округа Российской Федерачии», проведенного в январе-феврале 2010 года Северо-Осетинским иеентром соичальных исследований ИСПИ РАН совместно с Северо-Осетинским институтом гуманитарных и социальных исследований имени В.И. Абаева. Целью проведения данного исследования и написания данной работы было выяснение отношения населения региона к проблеме радикального ваххабизма. Для получения информации был проведен массовый опрос жителей республик СКФО, а также экспертный опрос. Материалы исследования показали, что в мононациональных республиках СКФО значение ислама и посещаемость мечетей заметно растут. Появление религиозного, идейно-политического течения ваххабизм, делающего ставку на личную духовность, привлекает многих жителей Северного Кавказа, потому что их пугают негативные проиессы, которые происходят в регионе. Ключевые слова: религиозное мировоззрение, кризис ислама, кризис иивилизачии, мусульманство, идеология, бедность, этнос, образ жизни, государство, община, традиции, эмиссары-миссионеры, исламское государство, ваххабить-радикальь, джихад
\end{abstract}

аспространение ваххабизма ${ }^{1}$ в республиках СКФО во многом связано с кризисом ислама. Такие кризисы в православии имели место в России в эпоху Петра Великого, когда произошла ликвидация патриаршества ${ }^{2}$.

\footnotetext{
1 Ваххабизм - название религиозно-политического движения в суннитском исламе, возникшего в Аравии в середине XVIII века на основе учения Мухаммада ибн 'Абд аль-Ваххаба и ставшего впоследствии идеологией первого государства Саудитов. Ваххабитское движение выросло из богословской полемики по поводу очищения ислама от еретических нововведений (бида') и критериев истинного единобожия (таухид) и превратилось впоследствии в мощный фактор идейно-политической жизни мусульманского мира // См. более подробно: Социологическая энциклопедия. Т. І. М., 2003. С. 132.

2 В 1721 г. Петр I утвердил Духовный регламент, составление которого было поручено псковскому епископу Феофану Прокоповичу. В результате произошла коренная реформа церкви, ликвидировавшая автономию духовенства и полностью подчинившая его государству. В России было упразднено патриаршество и учреждена Духовная коллегия, вскоре переименованная в Святейший Синод.
}

Как правило, в эпоху кризиса цивилизация подрывает консервативные формы любой религии, и они начинают - для самозащиты - приобретать более крайние формы. Одной из таких форм является идейно-политическое движение ваххабизм. Его быстрое распространение во всем мусульманском мире можно рассматривать как признак кризиса, но не идеологии, а кризиса образа жизни, традиционных устоев, быта и т. д. Это скорее способ привлечения масс, потому что бедность сама по себе не ведет к расколу внутренних социальных связей. Кризис переживает сам мусульманский мир, это можно видеть на примере автохтонных этносов республик СКФО, которые сплачиваются на основе единства образа жизни. Тут проблема не в религиозности. Если бы это было так, то религия была бы сама по себе, а образ жизни, государство, община - сами по себе. Дело в том, что религия является частью традиции, стала образом жизни, сутью народа. А раз образ жизни начинает ломаться, то начинают ломаться и принципы самой религии, и она теряет идеологию. 


\section{Внутренние угрозы и контрмеры}

В странах, где ваххабизм получил распространение, цель та же - связать народы воедино, создать некую новую целостность, исходным материалом для которой служит не территория, а этносы и субэтносы. В свою очередь, этническая принадлежность не является сдерживающим фактором для распространения идей ваххабизма, который как никакой другой толк в исламе придерживается догмата «религия превыше этнической принадлежности».

Почему же ваххабизм появился и быстро распространяется на Северном Кавказе? Главными очагами ваххабизма в СКФО являются Дагестан и Карачаево-Черкесия. Эти республики более других многонациональны. В Карачаево-Черкесии помимо русских (в том числе казачьего субэтноса) проживают четыре коренных народа: карачаевцы, черкесы, абазины и кубанские ногайцы. Что касается Дагестана, то положение здесь уникально: по-видимому, нигде в мире оно не встречается: Дагестан населен почти тридцатью этносами (частично, может быть, субэтносами). Причины такого положения в общих чертах ясны. Дагестан - «страна гор», к тому же изрезанных глубокими ущельями. Это всегда способствовало консервации древних языковых и культурных особенностей. Иными словами, в Дагестане всегда шел процесс, диаметрально противоположный тому, что наблюдается почти во всем остальном мире. Своеобразным «консервирующим» фактором стали многовековые иноземные вторжения на Кавказ, изза которых отдельным народам или целым группам народов приходилось укрываться в горах. Правда, какой-то симбиоз этносов все же происходил: восемь дагестанских народов консолидировались вокруг аварцев, четыре - вокруг лезгин, три - вокруг кумыков. Основой такой - относительной — консолидации была языковая близость. Сегодня главным связующим звеном между народами Дагестана был и остается русский язык. Сходную роль русский язык играет и в Карачаево-Черкесии.

Теперь, когда определенные силы как за пределами Северного Кавказа, так и в самом этом регионе, делают ставку на выход (в целом или хотя бы части региона) из состава Российской Федерации, народам нужно цементирующее начало. И как когда-то в Саудовской Аравии ваххабизм был призван идеологически объединить феодально раздробленные земли, так сегодня единение, цементирование полиэтничных республик (а в более далекой перспективе - республик между собой) видят все в том же ваххабизме.
Ваххабитские эмиссары-миссионеры прибывают на Северный Кавказ, прежде всего в Дагестан и Карачаево-Черкесию, из Пакистана, Иордании и даже из Саудовской Аравии. Вербовка сторонников проводится самыми разными способами. К тому же, судя по данным полевых этнографических исследований, каждый новый приверженец ваххабизма получает 5 тысяч долларов. Для многих жителей северокавказских республик сумма эта настолько велика, что известны случаи, когда принимают ислам и становятся ваххабитами местные русские.

В том виде, в котором в настоящее время ваххабизм распространяется на Северном Кавказе, он не представляет собой цельной идеологии. Не вдаваясь в детали, среди ваххабитов можно выделить два крыла - реформистское и радикальное. Сверхзадача одна: исламизация всего региона и в конечном счете создание на всей территории Северного Кавказа независимого исламского государства. Но тактика различна. Имам всех ваххабитов России (то есть не только северокавказских, но и поволжских) Нажмутдин Нажмутдинов, имеющий свою резиденцию в Москве, - реформатор. Он считает, что программа распространения ваххабизма должна быть рассчитана лет на двадцать, а провозглашенный Кораном джихад (священная война против «неверных») в данное время должен вестись мирными средствами: строительство мечетей, обучение основам ислама, разъяснительная работа среди населения, распространение листовок и литературы. Наряду с этим ваххабизм реформистского толка предполагает также критику государственного строя, обращение к насущным экономическим проблемам, борьбу со взяточничеством, коррупцией и нищетой. Входит сюда и резкая критика официального мусульманского духовенства, которое обвиняется в незнании Корана и Сунны, отходе от шариата и т. п.

В отличие от ваххабитов-«реформаторов» для ваххабитов-радикалов основной целью деятельности является джихад - вооруженная борьба (война) с немусульманами. При этом и те, и другие ваххабиты выступают против «новшеств» («бида»), хотя и пользуются, подобно аравийским ваххабитам, всеми достижениями современной технической цивилизации; они также выступают против употребления спиртного, табака и наркотиков. Как и положено истинным мусульманам, они призывают к созданию крепких многодетных семей (ислам строжайшим образом запрещает использование противозачаточных средств). Небезынтересный штрих. В то время как 


\section{Национальная безопасность $1(24) \cdot 2013$}

на Северном Кавказе традиционно запрещены кросскузенные браки (браки с дочерью брата матери или сестры отца), моджахеды, следуя шариату, считают их вполне допустимыми.

Многое в реформизме или радикализме местных ваххабитов зависит от их глав - «эмиров» и подчиненных им «шейхов». Число приверженцев ваххабизма растет, хотя есть сведения и об отошедших от ваххабизма мусульманах. В Карачаево-Черкесии, где ваххабитов, по мнению экспертов, насчитывается более трехсот человек, преобладает ваххабизм реформистского толка. В Дагестане ваххабитов больше, но реальной поддержки среди населения это течение не находит. Настроены они по отношению к властям менее миролюбиво, особенно в более религиозном равнинном Дагестане, населенном преимущественно аварцами, даргинцами, лезгинами, ногайцами и кумыками.

Благоприятной почвой для деятельности ваххабитов здесь являются этнотерриториальные конфликты, к примеру кумыкско-горский. Когда значительная часть дагестанских горцев была переселена в равнинный Дагестан, на земли, которые кумыки считают своими, возникла межэтническая напряженность. Она еще больше усилилась с возвращением депортированных чеченцев, часть которых (чеченцы-аккинцы) также была жителями этих земель. В этот затянувшийся конфликт в последнее время вмешались ваххабиты, которые сочли своим священным долгом уладить дело по шариатской справедливости. К этому надо добавить, что идеология и практика ваххабизма начинают влиять и на бытовую сторону жизни. В 1998 г. в Буйнакске была похищена малолетняя девочка, что, как известно, запрещено шариатом, похитителя со средневековой жестокостью сожгли заживо.

Своеобразная ситуация с ваххабитами складывалась в Чечне-Ичкерии. В то время как в Российской Федерации неэкстремистский, реформистский ваххабизм был зарегистрирован как полноправное вероучение, т. е. легализован, самоутверждающиеся власти Чечни его запретили. Указом президента республики он был объявлен вне закона, нескольких ваххабитских миссионеров-иорданцев выдворили из страны. В середине июля 1998 г. в Гудермесе ваххабиты выступили против сил шариатского министерства безопасности. Исламский полк особого назначения, ориентированный на ваххабизм, под командованием иорданца чеченского происхождения полковника Хаттаба вступил в бой с шариатской гвардией. После этого проваххабитские вооруженные соединения были расформированы, однако не подчинились приказу и отошли к селению Атаги.

Таким образом, религиозное знамя ваххабизма как нельзя более кстати оказалось в руках тех, кто намерен оторвать Северный Кавказ или его часть от России. Таковы были реалии религиозной ситуации на Северном Кавказе, которые, несомненно, и сегодня сказываются на общественно-политической обстановке в целом и поэтому требуют внимательного анализа со стороны российских и региональных политиков.

Для полноценной реализации целей и задач исследования по теме «Распространение религиозного течения ваххабизм в СКФО РФ: этносоциологический анализ» в каждой республике СКФО РФ в январе-феврале 2010 г. был проведен репрезентативный опрос. Целесообразный объем выборки в каждой республике составил 500 респондентов и 5 экспертов. Общий объем выборки для семи республик составил соответственно 3500 респондентов (из них $50 \%$ - коренное население и $50 \%$ - русские и русскоязычные) и 35 экспертов. Математическая погрешность такой выборки не превышает $1,4 \%$, то есть обеспечивает надежную репрезентативность для каждого обследуемого субъекта Российской Федерации. Для проведения опроса в каждой республике выборка строилась как территориальная, стратифицированная по типам населенных пунктов, маршрутная, квотная по социально-демографическим и национальным признакам. Конкретные параметры выборки, построенные на основании данных государственной статистики по каждой республике, приведены ниже.

Чтобы определить масштаб распространения, для уточнения масштаба распространения ваххабизма, мы включили в инструмент исследования вопрос: «Как Вы думаете, а в Вашем городе (селе) есть люди, группы людей, которые исповедуют ваххабизм?» (таблица 1). Реальное положение ваххабизма на Северном Кавказе оценивало не только автохтонное население этого края, но и русское и русскоязычное население, проживающее здесь, эта группа респондентов дает более независимую оценку уровня распространенности ваххабизма в регионе.

В Адыгее 55,2 \% адыгейцев и 52,8 \% русских и русскоязычных ответили «нет», а $37,3 \%$ адыгейцев и $31,7 \%$ русских и русскоязычных затруднились или 
Внутренние угрозы и контрмеры

отказались от ответа. В КБР 55,1 \% кабардинцев, балкарцев и 47,6 \% русских и русскоязычных считают, что там, где они проживают, есть сторонники ваххабизма, но 41,3 \% русских и русскоязычных и $30,5 \%$ респондентов коренных национальностей затруднились с ответом или отказались отвечать. В КЧР 46,2 \% русских и русскоязычных и $30,1 \%$ карачаевцев и черкесов считают, что в их городе (селе) есть ваххабиты. 33,3 \% русских и русскоязычных и $31,5 \%$ карачаевцев и черкесов, напротив, считают, что там, где они живут, приверженцев ваххабизма нет. 38,4 \% карачаевцев и черкесов и 20,4 \% русских и русскоязычных КЧР затруднились с ответом или отказались отвечать.

40,7 \% респондентов - представителей народов Дагестана и $31 \%$ русских и русскоязычных согласны с тем, что в их местности есть ваххабиты. Но почти столько же респондентов РД - представителей обеих групп по разным причинам отказались отвечать.

В Ингушетии затруднились или отказались отвечать $60 \%$ русских и русскоязычных и 50,9\% ингушей. Только 20,8 \% ингушей и $6,7 \%$ русских и русскоязычных считают, что там, где они живут, есть люди, исповедующие ваххабизм. В РСО-А 34,9 \% русских и русскоязычных и $23 \%$ осетин думают, что в их городе (селе) есть ваххабиты, но 46,5 \% русских и русскоязычных и 40,7 \% отказались от ответа. В ЧР $40 \%$ русских и русскоязычных и 13,5 \% чеченцев полагают, что там, где они проживают, есть приверженцы ваххабизма. Но каждый второй респондент обеих групп по национальному признаку отказался под разными предлогами отвечать на поставленный вопрос.

Таблица 1

Как Bы думаете, а в Вашем городе (селе) есть люди, группы людей, которые исповедуют религиозное течение ваххабизм? $(8 \%)$

\begin{tabular}{|c|c|c|c|c|c|c|c|}
\hline \multirow[b]{2}{*}{ 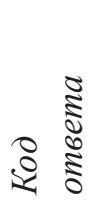 } & \multirow[b]{2}{*}{ Варианты ответа } & \multicolumn{2}{|c|}{ PA } & \multicolumn{2}{|c|}{ КБР } & \multicolumn{2}{|c|}{ КЧР } \\
\hline & & адыгейцы & $\begin{array}{c}\text { русские } \\
\text { и русско- } \\
\text { язычные }\end{array}$ & $\begin{array}{c}\text { кабар- } \\
\text { динцы, } \\
\text { балкарцы }\end{array}$ & $\begin{array}{c}\text { русские } \\
\text { и русско- } \\
\text { язычные }\end{array}$ & $\begin{array}{c}\text { карача- } \\
\text { евцы, } \\
\text { черкесы }\end{array}$ & $\begin{array}{c}\text { русские } \\
\text { и русско- } \\
\text { язычные }\end{array}$ \\
\hline 1 & Есть & 7,5 & 15,6 & 55,1 & 47,6 & 30,1 & 46,2 \\
\hline 2 & Нет & 55,2 & 52,8 & 14,4 & 11,1 & 31,5 & 33,3 \\
\hline 3 & $\begin{array}{l}\text { Затрудняюсь ответить, } \\
\text { отказ от ответа }\end{array}$ & 37,3 & $-31,7$ & $-30,5$ & $4-1,3$ & 38,4 & 20,4 \\
\hline & & 100,0 & 100,0 & 100,0 & 100,0 & 100,0 & 100,0 \\
\hline
\end{tabular}

\begin{tabular}{|c|c|c|c|c|c|c|c|c|}
\hline \multirow[b]{2}{*}{ 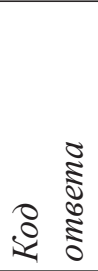 } & \multicolumn{2}{|c|}{ РД } & \multicolumn{2}{|c|}{ РИ } & \multicolumn{2}{|c|}{ PCO-A } & \multicolumn{2}{|c|}{ ЧР } \\
\hline & $\begin{array}{c}\text { народы } \\
\text { Дагестана }\end{array}$ & $\begin{array}{l}\text { русские } \\
\text { и русско- } \\
\text { язычные }\end{array}$ & ингуши & $\begin{array}{c}\text { русские } \\
\text { и русско- } \\
\text { язычные }\end{array}$ & осетины & $\begin{array}{l}\text { русские } \\
\text { и русско- } \\
\text { язычные }\end{array}$ & чеченцы & $\begin{array}{c}\text { русские } \\
\text { и русско- } \\
\text { язычные }\end{array}$ \\
\hline 1 & 40,7 & 31,0 & 20,8 & 6,7 & 23,0 & 34,9 & 13,5 & 40,0 \\
\hline 2 & 13,8 & 27,6 & 28,3 & 33,3 & 36,4 & 18,6 & 34,1 & 10,0 \\
\hline 3 & 45,5 & 41,4 & 50,9 & 60,0 & 40,7 & 46,5 & 52,4 & 50,0 \\
\hline & 100,0 & 100,0 & 100,0 & 100,0 & 100,0 & 100,0 & 100,0 & 100,0 \\
\hline
\end{tabular}




\section{Национальная безопасность $1(24) \cdot 2013$}

На прямой вопрос о наличии сторонников ваххабизма в местах проживания респондентов подавляющее большинство как коренного, так и русского и русскоязычного населения КЧР и РД дало положительный ответ. Так же ответили русские и русскоязычные респонденты - жители РСО-А и ЧР.

Как видим, ислам в республиках СКФО становится одним из основных ценностно-символических комплексов, существенно влияющим на ситуацию в регионе. Религиозная практика предполагает различные дискурсы и прежде, чем говорить о характере и формах политизации ислама, нужно определить те смысловые поля, в которых этот феномен приобретает свое современное содержание.

Переход ислама в радикальную фазу, во-первых, связан с борьбой разных типов национальных элит в республиках, за которой в перспективе вырисовываются две разные модели ислама как фактора политики. Во-вторых, существенное значение имеет, кто именно получает возможность занять верхние позиции на вертикали власти, какая социокультурная традиция воспроизводится благодаря этому продвижению. Появление радикальной «альтернативной» элиты обусловлено разрывом (фрагментацией) традиционных социальных связей, размыванием сельской общины и переездом части сельского населения в город, разложением самой насыщенной первичными узами социальной среды. В городе утерянные социальные связи мифологизируются и становятся парадоксальной моделью для иного общественно-политического порядка, выстроенного на священных традиционных устоях как подлинных оснований для справедливого социального переустройства. Эти основания «открываются» как истинное, национальное - с тем большей отчетливостью, чем более явной оказывается связь старой элиты с инонациональной государственной властью или «западным тлетворным влиянием»³.

Что касается влияния гендерной принадлежности опрошенных на выбор варианта ответа, то в ходе опроса был отмечены некоторые отличия мнений относительно наличия сторонников ваххабизма в местах проживания респондента (таблица 1.1).

«Есть» - так считают 58,2 \% русских и русскоязычных женщин КБР, 55,8 \% мужчин-кабардинцев, балкарцев, 53,9 \% кабардинок, балкарок, 53,1 \% русских и русскоязычных мужчин, 42,6 \% русских

${ }^{3}$ Дзуиев Х. В., Цуичев А. А. Указ. соч. С. 17. и русскоязычных женщин КЧР, 41,7 \% русских и русскоязычных мужчин, 41,2 \% женщин народов Дагестана, 35,7 \% русских и русскоязычных мужчин КБР, 35,1 \% русских и русскоязычных РД, 30,3\% мужчин карачаевцев и черкесов, 30 \% женщин карачаевцев и черкесов. 67,9\% мужчин-адыгейцев и $46,2 \%$ адыгеек считают, что в их городе (селе) не проживают люди, исповедующие ваххабизм. Не стали отвечать на вопрос 46,2 \% адыгеек и каждый четвертый мужчина-адыгеец. Такой же разрыв в ответах русских и русскоязычных мужчин и женщин (60,5 \% и 46,9 \% соответственно). Каждая третья женщина и почти каждый третий мужчина по разным причинам отказались от ответа. В КБР более чем каждый второй респондент, мужчины и женщины, подтверждает, что там, где он проживает, есть люди, исповедующие ваххабизм. Но каждый третий респондент обоих полов затруднился или отказался отвечать на вопрос. 58,2 \% женщин и 35,7 \% русских и русскоязычных мужчин КБР считают, что в их городе (селе) есть ваххабиты. Каждый второй русский и русскоязычный мужчина и каждая третья русская и русскоязычная женщина в КБР отказались от ответа на этот вопрос. В КЧР вариант «есть» равно выбрали респонденты коренной национальности и мужчины, и женщины: почти каждый третий мужчина карачаевец и черкес $(30,3 \%)$ и почти каждая третья карачаевка, черкешенка (30 \%). 39,4 \% мужчин карачаевцев и черкесов полагают, что в их городе (селе) нет ваххабизма, каждая четвертая карачаевка, черкешенка (25\%) поддерживает это мнение. Почти каждая вторая женщина из коренных национальностей КЧР затруднилась с ответом или отказалась отвечать, так же проявили себя 30,3 \% мужчин коренных народов КЧР. 53,1 \% русских и русскоязычных мужчин КЧР считают, что в местности, где они проживают, есть люди, группы людей, которые исповедуют ваххабизм. Надо отметить, что русские и русскоязычные мужчины КЧР активнее отвечали на вопрос, только 12,5 \% из них затруднились с ответом или отказались отвечать. В РД среди коренных народов 41,2 \% женщин и 40,7 \% мужчин утвердительно ответили о наличии ваххабитов в населенных пунктах, где они проживают. Почти такое же число респондентов (женщин 49,4 \%, мужчин 42 \%) отказались отвечать или затруднились с ответом. Среди русских и русскоязычных респондентов - жителей РД $35,1 \%$ женщин и $26 \%$ мужчин считают, что в их городе (селе) есть сторонники ваххабизма, 31,2 \% мужчин и $24,7 \%$ русских и русскоязычных женщин 
Внутренние угрозы и контрмеры

полагают, что нет. 42,9 \% мужчин и 40,2 \% женщин вообще не ответили на вопрос. Каждый второй респондент-ингуш - мужчины и женщины - не стал отвечать на вопрос, каждая третья ингушка $(31,4 \%)$ и каждый четвертый ингуш (25,5%) считают, что в их местности приверженцев ваххабизма нет. Русские и русскоязычные РИ предпочли не отвечать $(66,7 \%$ мужчин и 55,6 \% женщин). В РСО-А 27,1 \% осетинок и 17,6 \% мужчин-осетин высказались за первый вариант ответа положительно, $39,6 \%$ мужчин и $33,9 \%$ женщин коренной национальности ответили «нет», $42,9 \%$ мужчин-осетин и $39 \%$ осетинок затруднились с ответом или отказались отвечать. Среди русских и русскоязычных РСО-А 41,7 \% мужчин и 30 \% женщин считают, что в населенных пунктах, где они проживают, ваххабиты есть. 56 \% русских и русскоязычных женщин и 33,3 \% русских и русскоязычных мужчин ушли от ответа. В ЧР 40,2 \% мужчин-чеченцев и $28,6 \%$ чеченок на первый вариант ответили утвердительно, 58,2 \% чеченок и 46 \% мужчин-чеченцев воздержались от ответа. Русские и русскоязычные Чеченской Республики высказались несколько иначе: $41,9 \%$ русских и русскоязычных женщин и $37,8 \%$ русских и русскоязычных мужчин считают, что там, где они живут, есть люди, исповедующие ваххабизм. Среди русских и русскоязычных респондентов также высок процент затруднившихся с ответом: $51,2 \%$ женщин и 48,6 \% мужчин.

Таблица 1.1

Как Вы думаете, а в Вашем городе (селе) есть люди, группы людей, которые исповедуют религиозное течение ваххабизм? (в \%)

\begin{tabular}{|c|c|c|c|c|c|c|c|c|c|}
\hline \multirow{3}{*}{ 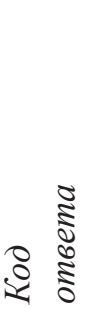 } & \multirow{3}{*}{ Варианты ответа } & \multicolumn{4}{|c|}{ PA } & \multicolumn{4}{|c|}{ КБР } \\
\hline & & \multicolumn{2}{|c|}{ адыгейцы } & \multicolumn{2}{|c|}{$\begin{array}{l}\text { русские и рус- } \\
\text { скоязычные }\end{array}$} & \multicolumn{2}{|c|}{$\begin{array}{c}\text { кабардинцы, } \\
\text { балкарцы }\end{array}$} & \multicolumn{2}{|c|}{$\begin{array}{l}\text { русские и рус- } \\
\text { скоязычные }\end{array}$} \\
\hline & & муж. & жен. & муж. & жен. & муж. & жен. & муж. & жен. \\
\hline 1 & Есть & 7,1 & 7,7 & 10,5 & 19,5 & 55,8 & 53,9 & 35,7 & 58,2 \\
\hline 2 & Нет & 67,9 & 46,2 & 60,5 & 46,9 & 11,7 & 16,9 & 16,1 & 7,5 \\
\hline 3 & $\begin{array}{l}\text { Затрудняюсь ответить, } \\
\text { отказ от ответа }\end{array}$ & 25,0 & 46,2 & 29,1 & 33,6 & 32,5 & 29,2 & 48,2 & 34,3 \\
\hline & & 100,0 & 100,0 & 100,0 & 100,0 & 100,0 & 100,0 & 100,0 & 100,0 \\
\hline
\end{tabular}

\begin{tabular}{|c|c|c|c|c|c|c|c|c|}
\hline \multirow{3}{*}{ 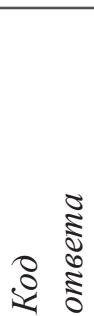 } & \multicolumn{4}{|c|}{ КЧР } & \multicolumn{4}{|c|}{ РД } \\
\hline & \multicolumn{2}{|c|}{ карачаевцы, черкесы } & \multicolumn{2}{|c|}{$\begin{array}{c}\text { русские и русско- } \\
\text { язычные }\end{array}$} & \multicolumn{2}{|c|}{ народы Дагестана } & \multicolumn{2}{|c|}{$\begin{array}{c}\text { русские и русско- } \\
\text { язычные }\end{array}$} \\
\hline & муж. & жен. & муж. & жен. & муж. & жен. & муж. & жен. \\
\hline 1 & 30,3 & 30,0 & 53,1 & 42,6 & 40,7 & 41,2 & 26,0 & 35,1 \\
\hline 2 & 39,4 & 25,0 & 34,4 & 32,8 & 17,3 & 9,4 & 31,2 & 24,7 \\
\hline 3 & 30,3 & 45,0 & 12,5 & 24,6 & 42,0 & 49,4 & 42,9 & 40,2 \\
\hline
\end{tabular}




\section{Национальная безопасность 1(24) • 2013}

\begin{tabular}{|c|c|c|c|c|c|c|c|c|}
\hline \multirow[b]{3}{*}{ 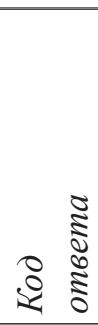 } & \multicolumn{4}{|c|}{ КЧР } & \multicolumn{4}{|c|}{ РД } \\
\hline & \multicolumn{2}{|c|}{ карачаевцы, черкесы } & \multicolumn{2}{|c|}{$\begin{array}{c}\text { русские и русско- } \\
\text { язычные }\end{array}$} & \multicolumn{2}{|c|}{ народы Дагестана } & \multicolumn{2}{|c|}{$\begin{array}{c}\text { русские и русско- } \\
\text { язычные }\end{array}$} \\
\hline & муж. & жен. & муж. & жен. & муж. & жен. & муж. & жен. \\
\hline & 100,0 & 100,0 & 100,0 & 100,0 & 100,0 & 100,0 & 100,0 & 100,0 \\
\hline
\end{tabular}

\begin{tabular}{|c|c|c|c|c|c|c|c|c|c|c|c|c|}
\hline \multirow{3}{*}{ 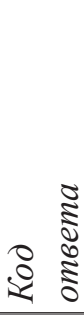 } & \multicolumn{4}{|c|}{ РИ } & \multicolumn{4}{|c|}{ PCO-A } & \multicolumn{4}{|c|}{ ЧР } \\
\hline & \multicolumn{2}{|c|}{ ингуши } & \multicolumn{2}{|c|}{$\begin{array}{c}\text { русские и } \\
\text { русскоязычные }\end{array}$} & \multicolumn{2}{|c|}{ осетины } & \multicolumn{2}{|c|}{$\begin{array}{c}\text { русские и } \\
\text { русскоязычные }\end{array}$} & \multicolumn{2}{|c|}{ чеченцы } & \multicolumn{2}{|c|}{$\begin{array}{c}\text { русские и } \\
\text { русскоязычные }\end{array}$} \\
\hline & муж. & жен. & муж. & жен. & муж. & жен. & муж. & жен. & муж. & жен. & муж. & жен. \\
\hline 1 & 23,6 & 17,6 & 0,0 & 11,1 & 17,6 & 27,1 & 41,7 & 30,0 & 13,8 & 13,3 & 37,8 & 41,9 \\
\hline 2 & 25,5 & 31,4 & 33,3 & 33,3 & 39,6 & 33,9 & 25,0 & 14,0 & 40,2 & 28,6 & 13,5 & 7,0 \\
\hline 3 & 50,9 & 51,0 & 66,7 & 55,6 & 42,9 & 39,0 & 33,3 & 56,0 & 46,0 & 58,2 & 48,6 & 51,2 \\
\hline & 100,0 & 100,0 & 100,0 & 100,0 & 100,0 & 100,0 & 100,0 & 100,0 & 100,0 & 100,0 & 100,0 & 100,0 \\
\hline
\end{tabular}

Высказали свое мнение и эксперты. Они считают, что это движение в настоящее время находится в латентной форме - открыто исповедующих и проповедующих ваххабизм отдельных людей или групп в населенных пунктах — селах и городах региона нет, они рассеялись, ушли в подполье или эмигрировали. Однако идеология ваххабизма в СКФО живет в умах людей, и если не предпринять меры, его влияние будет возрастать.

Была также выявлена некоторая зависимость суждений по рассматриваемому вопросу от возраста респондента (таблица 1.2).

Положительно на вопрос, есть ли в вашем городе (селе) люди или группы людей — сторонников ваххабизма, ответили: $63,2 \%$ кабардинцев и балкарцев моложе 35 лет, 51,6\% - русских и русскоязычных в КБР, 49,5 \% кабардинцев и балкарцев старше 35 лет, $48,5 \%$ - русских и русскоязычных в КЧР старше 35 лет, 47,1 \% респондентов - представителей народов Дагестана моложе 35 лет, 46,3 \% русских и русскоязычных респондентов - жителей КБР старше 35 лет, 41,4 \% русских и русскоязычных в
ЧР до 35 лет, 40,7 \% русских и русскоязычных в КЧР до 35 лет, 39,2 \% русских и русскоязычных ЧР старше 35 лет, 36,4 \% коренных народов РД старше 35 лет, 35,8\% карачаевцев и черкесов моложе 35 лет, $35,7 \%$ русских и русскоязычных в РСО-А старше 35 лет, 33,3 \% русских и русскоязычных в РСО-А моложе 35 лет, 31,8 \% русских и русскоязычных в РД до 35 лет, 30,9 \% - старше 35 лет, 25 \% русских и русскоязычных в РИ до 35 лет.

Второй вариант ответа - «нет» - выбрали: $68,3 \%$ русских и русскоязычных в РА моложе 35 лет, 60,0\% адыгейцев старше 35 лет, 48,7\% русских и русскоязычных в РА старше 35 лет, 45,5 \% адыгейцев до 35 лет и русских и русскоязычных РИ старше 35 лет, 40,6 \% осетин до 35 лет, 38,5 \% чеченцев старше 35 лет, 32,4 \% осетин старше 35 лет, $32 \%$ ингушей до 35 лет, 26,5 \% чеченцев до 35 лет, $25 \%$ ингушей старше 35 лет.

Затруднились с ответом или отказались отвечать: 75 \% русских и русскоязычных РИ до 35 лет, 61,8 \% чеченцев до 35 лет, каждый второй ингуш старше 35 лет (55,4 \%), русский и русскоязычный до 
Внутренние угрозы и контрмеры

35 лет (55,3 \%), русский и русскоязычный РИ старше 35 лет (54,5 \%), народы РД старше 35 лет (50,5 \%), адыгейцы до 35 лет (45,5 \%), кабардинцы, балкарцы старше 35 лет (44,2 \%), карачаевцы, черкесы старше 35 лет (40 \%), народы РД до 35 лет (38,2 \%), осетины до 35 лет (36,6 \%), кабардинцы, балкарцы старше 35 лет (36,4 \%), русские и русскоязычные РА старше 35 лет (33,5 \%), адыгейцы старше 35 лет (33,3\%), русские и русскоязычные КБР до 35 лет (32,3\%), русские и русскоязычные КЧР до 35 лет (25,9 \%).

Таблица 1.2

Как Вы думаете, а в Вашем городе (селе) есть люди, группы людей, которые исповедуют религиозное течение ваххабизм? (в \%)

\begin{tabular}{|c|c|c|c|c|c|c|c|c|c|}
\hline \multirow{3}{*}{ 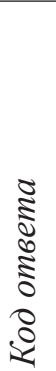 } & \multirow{3}{*}{ Варианты ответа } & \multicolumn{4}{|c|}{ PA } & \multicolumn{4}{|c|}{ КБР } \\
\hline & & \multicolumn{2}{|c|}{ адыгейцы } & \multicolumn{2}{|c|}{$\begin{array}{c}\text { русские } \\
\text { и русскоязычные }\end{array}$} & \multicolumn{2}{|c|}{$\begin{array}{c}\text { кабардинцы, } \\
\text { балкарцы }\end{array}$} & \multicolumn{2}{|c|}{$\begin{array}{c}\text { русские } \\
\text { и русскоязычные }\end{array}$} \\
\hline & & $\begin{array}{c}\text { до } \\
35 \text { лет }\end{array}$ & $\begin{array}{l}\text { старше } \\
35 \text { лет }\end{array}$ & $\begin{array}{c}\text { до } \\
35 \text { лет }\end{array}$ & $\begin{array}{c}\text { старше } \\
35 \text { лет }\end{array}$ & $\begin{array}{c}\text { до } \\
35 \text { лет }\end{array}$ & $\begin{array}{c}\text { старше } \\
35 \text { лет }\end{array}$ & $\begin{array}{c}\text { до } \\
35 \text { лет }\end{array}$ & $\begin{array}{l}\text { старше } \\
35 \text { лет }\end{array}$ \\
\hline 1 & Есть & 9,1 & 6,7 & 7,3 & 17,7 & 63,2 & 49,5 & 51,6 & 46,3 \\
\hline 2 & Нет & 45,5 & 60,0 & 68,3 & 48,7 & 14,7 & 14,1 & 16,1 & 9,5 \\
\hline 3 & $\begin{array}{l}\text { Затрудняюсь ответить, } \\
\text { отказ от ответа }\end{array}$ & 45,5 & 33,3 & 24,4 & 33,5 & 22,1 & 36,4 & 32,3 & 44,2 \\
\hline & & 100,0 & 100,0 & 100,0 & 100,0 & 100,0 & 100,0 & 100,0 & 100,0 \\
\hline
\end{tabular}

\begin{tabular}{|c|c|c|c|c|c|c|c|c|}
\hline \multirow{3}{*}{ 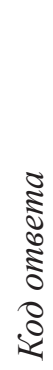 } & \multicolumn{4}{|c|}{ КЧР } & \multicolumn{4}{|c|}{ РД } \\
\hline & \multicolumn{2}{|c|}{ карачаевцы, черкесы } & \multicolumn{2}{|c|}{$\begin{array}{c}\text { русские и русско- } \\
\text { язычные }\end{array}$} & \multicolumn{2}{|c|}{ народы Дагестана } & \multicolumn{2}{|c|}{$\begin{array}{c}\text { русские и русско- } \\
\text { язычные }\end{array}$} \\
\hline & до 35 лет & $\begin{array}{l}\text { старше } \\
35 \text { лет }\end{array}$ & до 35 лет & $\begin{array}{l}\text { старше } \\
35 \text { лет }\end{array}$ & до 35 лет & $\begin{array}{l}\text { старше } \\
35 \text { лет }\end{array}$ & до 35 лет & $\begin{array}{c}\text { старше } \\
35 \text { лет }\end{array}$ \\
\hline 1 & 35,8 & 15,0 & 40,7 & 48,5 & 47,1 & 36,4 & 31,8 & 30,9 \\
\hline 2 & 28,3 & 40,0 & 33,3 & 33,3 & 14,7 & 13,1 & 22,7 & 28,3 \\
\hline 3 & 35,8 & 45,0 & 25,9 & 18,2 & 38,2 & 50,5 & 45,5 & 40,8 \\
\hline & 100,0 & 100,0 & 100,0 & 100,0 & 100,0 & 100,0 & 100,0 & 100,0 \\
\hline
\end{tabular}




\section{Национальная безопасность $1(24) \cdot 2013$}

\begin{tabular}{|c|c|c|c|c|c|c|c|c|c|c|c|c|}
\hline \multirow{3}{*}{ 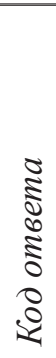 } & \multicolumn{4}{|c|}{ РИ } & \multicolumn{4}{|c|}{ PCO-A } & \multicolumn{4}{|c|}{ ЧР } \\
\hline & \multicolumn{2}{|c|}{ ингуши } & \multicolumn{2}{|c|}{$\begin{array}{l}\text { русские и рус- } \\
\text { скоязычные }\end{array}$} & \multicolumn{2}{|c|}{ осетины } & \multicolumn{2}{|c|}{$\begin{array}{c}\text { русские и рус- } \\
\text { скоязычные }\end{array}$} & \multicolumn{2}{|c|}{ чеченцы } & \multicolumn{2}{|c|}{$\begin{array}{c}\text { русские и рус- } \\
\text { скоязычные }\end{array}$} \\
\hline & $\begin{array}{c}\text { до } \\
35 \text { лет }\end{array}$ & $\begin{array}{l}\text { старше } \\
35 \text { лет }\end{array}$ & $\begin{array}{c}\text { до } \\
35 \text { лет }\end{array}$ & $\begin{array}{c}\text { старше } \\
35 \text { лет }\end{array}$ & $\begin{array}{c}\text { до } \\
35 \text { лет }\end{array}$ & $\begin{array}{c}\text { старше } \\
35 \text { лет }\end{array}$ & $\begin{array}{c}\text { до } \\
35 \text { лет }\end{array}$ & $\begin{array}{l}\text { старше } \\
35 \text { лет }\end{array}$ & $\begin{array}{c}\text { до } \\
35 \text { лет }\end{array}$ & $\begin{array}{l}\text { старше } \\
35 \text { лет }\end{array}$ & $\begin{array}{c}\text { до } \\
35 \text { лет }\end{array}$ & $\begin{array}{c}\text { старше } \\
35 \text { лет }\end{array}$ \\
\hline 1 & 22,0 & 19,6 & 25,0 & 0,0 & 22,8 & 23,1 & 33,3 & 35,7 & 11,8 & 14,5 & 41,4 & 39,2 \\
\hline 2 & 32,0 & 25,0 & 0,0 & 45,5 & 40,6 & 32,4 & 20,0 & 17,9 & 26,5 & 38,5 & 3,4 & 13,7 \\
\hline 3 & 46,0 & 55,4 & 75,0 & 54,5 & 36,6 & 44,4 & 46,7 & 46,4 & 61,8 & 47,0 & 55,2 & 47,1 \\
\hline & 100,0 & 100,0 & 100,0 & 100,0 & 100,0 & 100,0 & 100,0 & 100,0 & 100,0 & 100,0 & 100,0 & 100,0 \\
\hline
\end{tabular}

В зависимости от уровня образования респондентов были получены следующие ответы (таблица 1.3).

Ответили «есть» русские и русскоязычные КЧР со средним специальным образованием и ниже (49,2\%), русские и русскоязычные КБР с неоконченным высшим и высшим образованием $(49,1 \%)$, народы РД с неоконченным высшим и высшим образованием (48,5 \%), кабардинцы, балкарцы с неоконченным высшим и высшим образованием (47,9\%), русские и русскоязычные с неоконченным высшим и высшим образованием ЧР (45,5 \%), русские и русскоязычные РД с неоконченным высшим и высшим образованием (43,9\%), русские и русскоязычные КЧР с неоконченным высшим и высшим образованием $(43,8 \%)$, русские и русскоязычные с неоконченным высшим и высшим образованием РСО-А (43,4 \%), кабардинцы, балкарцы со средним специальным образованием и ниже и русские и русскоязычные со средним специальным образованием и ниже КБР (по 42,9 \%), карачаевцы, черкесы со средним специальным образованием и ниже $(38,9 \%)$, народы РД со средним специальным образованием и ниже (36,4 \%), карачаевцы, черкесы с неоконченным высшим и высшим образованием $(27,3 \%)$, русские и русскоязычные РА с неоконченным высшим и высшим образованием $(25,5$ \%), русские и русскоязычные РД со средним специальным образованием и ниже (25\%). Остальные группы не набрали легитимного большинства.

Вариант «нет» выбрали адыгейцы со средним специальным образованием и ниже $(58,1 \%)$, русские и русскоязычные РА со средним специальным образованием и ниже (54,2 \%), адыгейцы с неоконченным высшим и высшим образованием (50\%), русские и русскоязычные РИ с неоконченным высшим и высшим образованием (42,9 \%), осетины с неоконченным высшим и высшим образованием (40,8 \%), русские и русскоязычные РД со средним специальным образованием и ниже (39,7 \%), карачаевцы, черкесы со средним специальным образованием и ниже $(38,9$ \%),чеченцы со средним специальным образованием и ниже $(36,9 \%)$, русские и русскоязычные КЧР со средним специальным образованием и ниже $(33,9 \%)$, ингуши с неоконченным высшим и высшим образованием (32,6 \%), осетины со средним специальным образованием и ниже $(30,6 \%)$, чеченцы с неоконченным высшим и высшим образованием $(29,5 \%)$, русские и русскоязычные КЧР с неоконченным высшим и высшим образованием (28,1\%), ингуши со средним специальным образованием и ниже (27,6 \%). Остальные группы не набрали легитимного большинства.

Довольно много было респондентов, затруднившихся с ответом или отказавшихся отвечать, среди них: 71,4 \% русских и русскоязычных респондентов - жителей РИ со средним специальным образованием и ниже, 66,7 \% русских и русскоязычных в РСО-А со средним специальным образованием и ниже, 60,3 \% ингушей со средним специальным образованием и ниже, $57,1 \%$ русских и русскоязычных с неоконченным высшим и высшим образованием, $54,1 \%$ чеченцев с неоконченным высшим и высшим образованием, 52,6 \% русских и русскоязычных РД с неоконченным высшим и высшим образованием, со средним специальным образованием и ниже. Кроме того, каждый второй русский и русскоязычный респондент в ЧР со средним специальным 
Внутренние угрозы и контрмеры

образованием и ниже $(50,9 \%)$, чеченец со средним специальным образованием и ниже (50,8 \%), кабардинец и балкарец со средним специальным образованием и ниже $(45,7 \%)$, около половины респондентов — представителей народов РД — со средним специальным образованием и ниже и имеющие неоконченное высшее и высшее образование (по $45,5 \%), 44,9 \%$ русских и русскоязычных в КБР со средним специальным образованием и ниже, 43,6 \% карачаевцев и черкесов с неоконченным высшим и высшим образованием, по 41,7 \% кабардинцев, балкарцев и адыгейцев с неоконченным высшим и высшим образованием 41,2 \% осетин со средним специальным образованием и ниже, 40 \% осетин с неоконченным высшим и высшим образованием, 39,5 \% ингушей с неоконченным высшим и высшим образованием. Каждый третий русский и русскоязычный РД со средним специальным образованием и ниже $(35,3 \%)$, треть адыгейцев со средним специальным образованием и ниже $(34,9 \%)$, треть русских и русскоязычных со средним специальным образованием и ниже (34 \%), около трети русских и русскоязычных с неоконченным высшим и высшим образованием (28,1%). Каждый четвертый русский и русскоязычный РА с неоконченным высшим и высшим образованием $(25,5 \%)$.

Таблииа 1.3

Как Вы думаете, а в Вашем городе (селе) есть люди, группы людей, которые исповедуют религиозное течение ваххабизм? (в \%)

\begin{tabular}{|c|c|c|c|c|c|c|c|c|c|}
\hline \multirow[b]{3}{*}{ 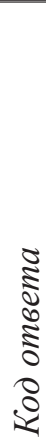 } & \multirow{3}{*}{ Варианты ответа } & \multicolumn{4}{|c|}{ PA } & \multicolumn{4}{|c|}{ КБР } \\
\hline & & \multicolumn{2}{|c|}{ адыгейцы } & \multicolumn{2}{|c|}{$\begin{array}{c}\text { русские и русско- } \\
\text { язычные }\end{array}$} & \multicolumn{2}{|c|}{$\begin{array}{c}\text { кабардинцы, бал- } \\
\text { карцы }\end{array}$} & \multicolumn{2}{|c|}{$\begin{array}{c}\text { русские и русско- } \\
\text { язычные }\end{array}$} \\
\hline & & $\begin{array}{c}\text { ср. } \\
\text { спец. и } \\
\text { ниже }\end{array}$ & $\begin{array}{c}\text { н/в, } \\
\text { высшее }\end{array}$ & $\begin{array}{c}\text { ср. } \\
\text { спец. и } \\
\text { ниже }\end{array}$ & $\begin{array}{c}\text { н/в, } \\
\text { высшее }\end{array}$ & $\begin{array}{c}\text { ср. } \\
\text { спец. и } \\
\text { ниже }\end{array}$ & $\begin{array}{c}\text { н/в, } \\
\text { высшее }\end{array}$ & $\begin{array}{c}\text { ср. } \\
\text { спец. и } \\
\text { ниже }\end{array}$ & $\begin{array}{c}\text { н/в, } \\
\text { высшее }\end{array}$ \\
\hline 1 & Есть & 7,0 & 8,3 & 11,8 & 25,5 & 42,9 & 47,9 & 42,9 & 49,1 \\
\hline 2 & Нет & 58,1 & 50,0 & 54,2 & 49,0 & 11,4 & 10,4 & 12,2 & 9,4 \\
\hline 3 & $\begin{array}{l}\text { Затрудняюсь ответить, } \\
\text { отказ от ответа }\end{array}$ & 34,9 & 41,7 & 34,0 & 25,5 & 45,7 & 41,7 & 44,9 & 41,5 \\
\hline & & 100,0 & 100,0 & 100,0 & 100,0 & 100,0 & 100,0 & 100,0 & 100,0 \\
\hline
\end{tabular}

\begin{tabular}{|c|c|c|c|c|c|c|c|c|}
\hline \multirow{3}{*}{ 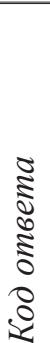 } & \multicolumn{4}{|c|}{ КЧР } & \multicolumn{4}{|c|}{ РД } \\
\hline & \multicolumn{2}{|c|}{ карачаевцы, черкесы } & \multicolumn{2}{|c|}{$\begin{array}{c}\text { русские и русско- } \\
\text { язычные }\end{array}$} & \multicolumn{2}{|c|}{ народы Дагестана } & \multicolumn{2}{|c|}{$\begin{array}{c}\text { русские и русско- } \\
\text { язычные }\end{array}$} \\
\hline & $\begin{array}{c}\text { ср. спец. и } \\
\text { ниже }\end{array}$ & $\begin{array}{c}\text { н/в, } \\
\text { высшее }\end{array}$ & $\begin{array}{c}\text { ср. спец. и } \\
\text { ниже }\end{array}$ & $\begin{array}{c}\text { н/в, } \\
\text { высшее }\end{array}$ & $\begin{array}{l}\text { ср. спец. и } \\
\text { ниже }\end{array}$ & $\begin{array}{c}\text { н/в, } \\
\text { высшее }\end{array}$ & $\begin{array}{c}\text { ср. спец. и } \\
\text { ниже }\end{array}$ & $\begin{array}{c}\text { н/в, } \\
\text { высшее }\end{array}$ \\
\hline 1 & 38,9 & 27,3 & 49,2 & 43,8 & 36,4 & 48,5 & 25,0 & 43,9 \\
\hline 2 & 38,9 & 29,1 & 33,9 & 28,1 & 18,2 & 6,1 & \begin{tabular}{|l|}
39,7 \\
\end{tabular} & 3,5 \\
\hline
\end{tabular}




\section{Национальная безопасность 1(24) • 2013}

\begin{tabular}{|c|c|c|c|c|c|c|c|c|}
\hline \multirow{3}{*}{ 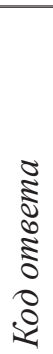 } & \multicolumn{4}{|c|}{ КЧР } & \multicolumn{4}{|c|}{ РД } \\
\hline & \multicolumn{2}{|c|}{ карачаевцы, черкесы } & \multicolumn{2}{|c|}{$\begin{array}{c}\text { русские и русско- } \\
\text { язычные }\end{array}$} & \multicolumn{2}{|c|}{ народы Дагестана } & \multicolumn{2}{|c|}{$\begin{array}{c}\text { русские и русско- } \\
\text { язычные }\end{array}$} \\
\hline & $\begin{array}{l}\text { ср. спец. и } \\
\text { ниже }\end{array}$ & $\begin{array}{c}\text { н/в, } \\
\text { высшеe }\end{array}$ & \begin{tabular}{|c|} 
ср. спец. и \\
ниже
\end{tabular} & $\begin{array}{c}\text { н/в, } \\
\text { высшее }\end{array}$ & $\begin{array}{c}\text { ср. спец. и } \\
\text { ниже }\end{array}$ & $\begin{array}{c}\text { н/в, } \\
\text { высшее }\end{array}$ & $\begin{array}{c}\text { ср. спец. и } \\
\text { ниже }\end{array}$ & $\begin{array}{c}\text { н/в, } \\
\text { высшее }\end{array}$ \\
\hline 3 & 22,2 & 43,6 & 16,9 & 28,1 & 45,5 & 45,5 & 35,3 & 52,6 \\
\hline & 100,0 & 100,0 & 100,0 & 100,0 & 100,0 & 100,0 & 100,0 & 100,0 \\
\hline
\end{tabular}

\begin{tabular}{|c|c|c|c|c|c|c|c|c|c|c|c|c|}
\hline \multirow[b]{3}{*}{ 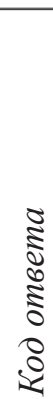 } & \multicolumn{4}{|c|}{ РИ } & \multicolumn{4}{|c|}{ PCO-A } & \multicolumn{4}{|c|}{ ЧР } \\
\hline & \multicolumn{2}{|c|}{ ингуши } & \multicolumn{2}{|c|}{$\begin{array}{c}\text { русские и рус- } \\
\text { скоязычные }\end{array}$} & \multicolumn{2}{|c|}{ осетины } & \multicolumn{2}{|c|}{$\begin{array}{c}\text { русские и рус- } \\
\text { скоязычные }\end{array}$} & \multicolumn{2}{|c|}{ чеченцы } & \multicolumn{2}{|c|}{$\begin{array}{c}\text { русские и рус- } \\
\text { скоязычные }\end{array}$} \\
\hline & $\begin{array}{c}\text { cp. } \\
\text { спец. и } \\
\text { ниже }\end{array}$ & $\begin{array}{l}\text { н/в, } \\
\text { выс- } \\
\text { шее }\end{array}$ & $\begin{array}{c}\text { ср. } \\
\text { спец. и } \\
\text { ниже }\end{array}$ & $\begin{array}{l}\text { н/в, } \\
\text { выс- } \\
\text { шее }\end{array}$ & $\begin{array}{c}\text { ср. } \\
\text { спец. и } \\
\text { ниже }\end{array}$ & $\begin{array}{c}\text { н/в, } \\
\text { выс- } \\
\text { шеe }\end{array}$ & $\begin{array}{c}\text { cp. } \\
\text { спец. и } \\
\text { ниже }\end{array}$ & $\begin{array}{l}\text { н/в, } \\
\text { выс- } \\
\text { шее }\end{array}$ & $\begin{array}{c}\text { ср. } \\
\text { спец. и } \\
\text { ниже }\end{array}$ & $\begin{array}{l}\text { н/в, } \\
\text { выс- } \\
\text { шее }\end{array}$ & $\begin{array}{c}\text { ср. } \\
\text { спец. и } \\
\text { ниже }\end{array}$ & $\begin{array}{l}\text { н/в, } \\
\text { выс- } \\
\text { шее }\end{array}$ \\
\hline 1 & 12,1 & 27,9 & 14,3 & 0,0 & 28,2 & 19,2 & 21,2 & 43,4 & 12,3 & 16,4 & 36,8 & 45,5 \\
\hline 2 & 27,6 & 32,6 & 14,3 & 42,9 & 30,6 & 40,8 & 12,1 & 22,6 & 36,9 & 29,5 & 12,3 & 4,5 \\
\hline 3 & 60,3 & 39,5 & 71,4 & 57,1 & 41,2 & 40,0 & 66,7 & 34,0 & 50,8 & 54,1 & 50,9 & 50,0 \\
\hline & 100,0 & 100,0 & 100,0 & 100,0 & 100,0 & 100,0 & 100,0 & 100,0 & 100,0 & 100,0 & 100,0 & 100,0 \\
\hline
\end{tabular}

Анализ зависимости ответов респондентов от уровня образования показал, что русское и русскоязычное население с неоконченным высшим и высшим образованием является объективным фоном практически во всех республиках. Опрошенные в целом подтверждают, что в таких республиках, как КБР, КЧР, РД и ЧР, идет интенсивное расширение влияния ваххабитской идеологии. Большую пассивность респондентов с неоконченным высшим или высшим образованием - представителей автохтонного населения республик СКФО можно объяснить тем, что даже незначительный выпад против сторонников ваххабизма чреват для них непредсказуемыми последствиями.

В зависимости от типа населенного пункта, в котором проживают респонденты, ответы на вопрос: «Как Вы думаете, а в Вашем городе (селе) есть люди, группы людей, которые исповедуют религиозное течение ваххабизм?» распределились следующим образом (таблица 1.4). Вариант «есть» выбрали респонденты: кабардинцы, балкарцы горожане $(56,5 \%)$, русские и русскоязычные горожане в КЧР (55,4 \%), кабардинцы, балкарцы и русские и русскоязычные сельчане в КБР (по $53,6 \%$ ), народы РД - горожане (51,9 \%), русские и русскоязычные горожане в РД (50,5\%), русские и русскоязычные горожане в КБР $(45,4 \%)$, русские и русскоязычные сельчане в ЧР $(43,1 \%)$, русские и русскоязычные горожане в РСО-А $(39,1 \%)$, русские и русскоязычные сельчане в КЧР $(32,4 \%)$, карачаевцы, черкесы сельчане $(32,3$ \%), представители народов Дагестана - сельчане (30,7 \%), карачаевцы и черкесы горожане $(28,6$ \%), ингуши горожане $(27,7 \%)$, русские и русскоязычные горо- 
Внутренние угрозы и контрмеры

жане в ЧР (26,7 \%). Остальные группы не набрали легитимный процент.

Второй вариант - «нет» - выбрали: русские и русскоязычные сельчане РА (64,6 \%), адыгейцы сельчане $(60 \%)$, русские и русскоязычные сельчане РД $(51,9 \%)$, русские и русскоязычные сельчане КЧР (51,4 \%), адыгейцы горожане (48,1%), чеченцы сельчане $(45,5 \%)$, русские и русскоязычные горожане в РА (41,7\%), ингуши сельчане (41,5 \%), русские и русскоязычные сельчане в РИ (40\%), карачаевцы, черкесы сельчане $(35,5$ \%), русские и русскоязычные горожане в РИ (30\%), карачаевцы и черкесы горожане (28,6 \%). Довольно много - по 60 \% - воздержавшихся среди русских и русскоязычных респондентов - сельчан и горожан в РИ. Отказались от ответа каждый второй чеченец горожанин (59,5 \%), русский и русскоязычный горожанин ЧР (53,3 \%), ингуш горожанин $(52,3$ \%), адыгеец горожанин (51,9\%), дагестанец сельчанин $(48,9 \%)$ и т. д.

Таблица 1.4

Как Вы думаете, а в Вашем городе (селе) есть люди, группы людей, которые исповедуют религиозное течение ваххабизм? (в \%)

\begin{tabular}{|c|c|c|c|c|c|c|c|c|c|}
\hline \multirow{3}{*}{ 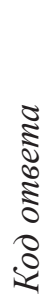 } & \multirow{3}{*}{ Варианты ответа } & \multicolumn{4}{|c|}{ PA } & \multicolumn{4}{|c|}{ КБР } \\
\hline & & \multicolumn{2}{|c|}{ адыгейцы } & \multicolumn{2}{|c|}{$\begin{array}{c}\text { русские и } \\
\text { русскоязычные }\end{array}$} & \multicolumn{2}{|c|}{$\begin{array}{c}\text { кабардинцы, } \\
\text { балкарцы }\end{array}$} & \multicolumn{2}{|c|}{$\begin{array}{c}\text { русские и } \\
\text { русскоязычные }\end{array}$} \\
\hline & & город & село & город & село & город & село & город & село \\
\hline 1 & Есть & 0,0 & 12,5 & 15,5 & 15,6 & 56,5 & 53,6 & 45,4 & 53,6 \\
\hline 2 & Нет & 48,1 & 60,0 & 41,7 & 64,6 & 14,5 & 14,4 & 12,4 & 7,1 \\
\hline 3 & $\begin{array}{l}\text { Затрудняюсь ответить, } \\
\text { отказ от ответа }\end{array}$ & 51,9 & 27,5 & 42,7 & 19,8 & 29,0 & 32,0 & 42,3 & 39,3 \\
\hline & & 100,0 & 100,0 & 100,0 & 100,0 & 100,0 & 100,0 & 100,0 & 100,0 \\
\hline
\end{tabular}

\begin{tabular}{|c|c|c|c|c|c|c|c|c|}
\hline \multirow{3}{*}{ 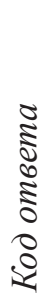 } & \multicolumn{4}{|c|}{ КЧР } & \multicolumn{4}{|c|}{ РД } \\
\hline & \multicolumn{2}{|c|}{ карачаевцы, черкесы } & \multicolumn{2}{|c|}{$\begin{array}{c}\text { русские и русско- } \\
\text { язычные }\end{array}$} & \multicolumn{2}{|c|}{ народы Дагестана } & \multicolumn{2}{|c|}{$\begin{array}{c}\text { русские и русско- } \\
\text { язычные }\end{array}$} \\
\hline & город & село & город & село & город & село & город & село \\
\hline 1 & 28,6 & 32,3 & 55,4 & 32,4 & 51,9 & 30,7 & 50,5 & 8,6 \\
\hline 2 & 28,6 & 35,5 & 21,4 & 51,4 & 6,3 & 20,5 & 6,5 & 51,9 \\
\hline 3 & 42,9 & 32,3 & 23,2 & 16,2 & 41,8 & 48,9 & 43,0 & 39,5 \\
\hline & 100,0 & 100,0 & 100,0 & 100,0 & 100,0 & 100,0 & 100,0 & 100,0 \\
\hline
\end{tabular}




\section{Национальная безопасность $1(24) \cdot 2013$}

\begin{tabular}{|c|c|c|c|c|c|c|c|c|c|c|c|c|}
\hline \multirow{3}{*}{ 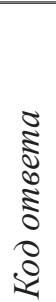 } & \multicolumn{4}{|c|}{ РИ } & \multicolumn{4}{|c|}{ PCO-A } & \multicolumn{4}{|c|}{ ЧР } \\
\hline & \multicolumn{2}{|c|}{ ингуши } & \multicolumn{2}{|c|}{$\begin{array}{c}\text { русские и } \\
\text { русскоязычные }\end{array}$} & \multicolumn{2}{|c|}{ осетины } & \multicolumn{2}{|c|}{$\begin{array}{c}\text { русские и } \\
\text { русскоязычные }\end{array}$} & \multicolumn{2}{|c|}{ чеченцы } & \multicolumn{2}{|c|}{$\begin{array}{c}\text { русские и } \\
\text { русскоязычные }\end{array}$} \\
\hline & город & село & город & село & город & село & город & село & город & село & город & село \\
\hline 1 & 27,7 & 9,8 & 10,0 & 0,0 & 21,7 & 24,5 & 39,1 & 17,6 & 20,2 & 7,9 & 26,7 & 43,1 \\
\hline 2 & 20,0 & 41,5 & 30,0 & 40,0 & 37,4 & 35,1 & 18,8 & 17,6 & 20,2 & 45,5 & 20,0 & 7,7 \\
\hline 3 & 52,3 & 48,8 & 60,0 & 60,0 & 40,9 & 40,4 & 42,0 & 64,7 & 59,5 & 46,5 & 53,3 & 49,2 \\
\hline & 100,0 & 100,0 & 100,0 & 100,0 & 100,0 & 100,0 & 100,0 & 100,0 & 100,0 & 100,0 & 100,0 & 100,0 \\
\hline
\end{tabular}

Как видно из таблицы 1.4, сказать однозначно, где живет больше людей (групп), исповедующих ваххабизм, - в селе или городе, по всей видимости, нельзя. В качестве гипотезы было предположение, что в сельской местности ваххабитов больше, но, судя по результатам опроса, большее распространение ваххабизм получил в городах и прежде всего в КБР, РД, КЧР. Только в селах ЧР, КЧР, РСО-А, по мнению наших респондентов, ваххабитов больше, чем в городах этих республик.

Широкое распространение ваххабизма в северокавказских республиках, на наш взгляд, тесно коррелирует со спецификой властных структур в регионе. Данный тип власти можно было бы назвать дотационным авторитаризмом. Его основные, важнейшие характеристики вполне определяются способом обретения финансовой и политической власти. Эту связку можно пунктирно обозначить следующими штрихами:

- способ дохода - трансферты и дотации из федерального центра;

- основание власти - распределение этих средств;

- $\quad$ пределы власти - способность к тиражированию лояльности в обмен на протекцию.

Само существование республиканских властных институтов оказывается средством доступа к федеральному бюджету как единственному надежному источнику средств. Кризис поступлений сразу оказывается кризисом власти, кризисом ее легитимности. В таких условиях социальной базой радикализации процесса исламского возрождения выступают социальные слои или этнотерриториальные общности, обделенные потоками бюджетных средств и имеющие альтернативные источники заработков.
Рассматривая республиканские элиты в контексте данного вопроса, в ней можно выделить три основные группы. Прежде всего это номенклатурная элита, опирающаяся - в идеологическом и хозяйственно-правовом аспекте - на распределение бюджетных средств. Как об отдельной группе можно говорить о бизнес-элите, которая вышла в основном из номенклатуры, но дистанцировалась от нее и обретает иной хозяйственный профиль. Идеология национальных бизнес-элит — это синкрезис патернализма (происхождение капитала), национализма (республика как налоговый плацдарм для общероссийского льготного оперирования) и либерализма (открытость, прозрачность границ и проч.). Эта группа - существенное препятствие для радикализации ислама в северокавказских республиках.

И, наконец, третья элитарная группа - образованная среда, состоящая из людей экономически неадаптированных к той хозяйственно-экономической конфигурации, которую выстроили для себя успешные северокавказские диаспоры в России. По мнению наших экспертов, эта группа является нишей радикального ислама, Обрести свой внутренний властный статус эта элита может, только опираясь на радикально-исламскую риторику.

Хозяйственной инфраструктурой для усиления такой элиты могут быть экономические связи с исламскими, арабскими странами, организационно-образованные кадры из учебных заведений Ирана, Иордании, Саудовской Аравии, возвращающиеся на родину и оказывающиеся естественными конкурентами этнических бизнес-элит, ориентированных на Россию, или номенклатурных элит, дотируемых Москвой. Свое место в политической и духовной жизни альтернативные элиты смогут обрести только в определенном социально-эконо- 
мическом контексте (сокращение тех социальных дивидендов, которые получают северокавказские общества от делового и политического «обращения» первых двух упомянутых нами национальных элит). Значительное расслоение, коррупция — вот выражение кризиса «национальной идеи» и почва исламизации. Потенциал таких «религиозных» элит прямо соотносится с количеством обучающихся в Турции, Иране и других арабских странах в расчете на душу населения; данной точки придерживаются как русские и русскоязычные эксперты, так и представители коренного населения республик СКФО 4 .

Можно сказать, что мусульманская часть населения хочет сохранить традиционный образ жизни, потому что боится раствориться среди немусульманской части населения. Она теряет под собой почву, не знает, как дальше жить, как сохранить устои семьи. Цивилизация, считает эта часть населения региона, настолько сильна, что может разрушить привычный уклад. Этот страх рождает склонность к крайним формам самозащиты, что является почвой для восприятия самых реакционных идеологий. Отсюда - масса шахидов, которые даже не думают о том, что у них есть дети, семьи. А их родители даже гордятся тем, что их сын или дочь убили себя во имя Аллаха. Значит, в них тоже «сидят» эти идеи - самоликвидация как форма освобождения от давления цивилизации. Принцип любого биологического существа — выжить. И только когда нет возможности выжить, происходит самоуничтожение. Это явление встречается в природе: киты выбрасываются на сушу, олени стадами идут в море. Так же и для этих народов цивилизация является тупиком. Почему? По всей видимости, чтобы ответить на этот вопрос, придется провести глубокий системный анализ. В неспокойных республиках — в Чечне, Дагестане, Ингушетии, Карачаево-Черкесии, Кабардино-Балкарии - все недочеты со стороны властных структур, все террористические и сепаратистские настроения связывают с ваххабизмом.
В свое время великий осетинский поэт Коста Хетагуров говорил, что наши беды исходят от безграмотных мулл. Религия регулирует мораль, поэтому, по мнению респондентов и экспертов, является мощным духовным и нравственным фактором. На одном законе далеко не уедешь, но необходимо найти баланс между вмешательством религиозных институтов - церкви, мечети - в жизнь людей и степенью их личной свободы, в том числе и вероисповедания. Респонденты считают, что религия - это личное дело человека. Не хочет кто-то соблюдать религиозные предписания - это его дело, важно не соблюдение догм и предписаний, а моральные устои и принципы. Подавляющее большинство опрошенных считают: если религия поддерживает моральный облик человека, укрепляет совесть и эта личность действительно ведет себя как человек в общении с другими - это польза. Если же религиозная вера провоцирует конфликты, сталкивает людей, пропагандирует превосходство той или иной конфессии, будь то иудаизм или христианство, тогда эта практика, считают респонденты, не годится для общества.

На вопрос «Как Вы относитесь к запрету религиозного течения ваххабизм в Российской Федерации?» респонденты ответили следующим образом (таблица 2). Первый вариант ответа: «безусловно положительно» выбрали русские и русскоязычные респонденты в PCO-А (74,7\%), русские и русскоязычные в ЧР (67,5\%), представители коренных национальностей в РД (65,9\%), русские и русскоязычные в РА (59,6 \%), русские и русскоязычные в КЧР $(58,7 \%)$, русские и русскоязычные в РД (55,8 \%), осетины (53,6\%), кабардинцы, балкарцы и карачаевцы, черкесы (по 52,1 \%), русские и русскоязычные в РИ (50,0 \%), русские и русскоязычные КБР (48,8 \%), ингуши (39,3 \%). Надо отметить, что меньше всего из тех, кто выбрал вариант «безусловно положительно», респондентов-адыгейцев $(24,7 \%)$, они же чаще всего затруднялись с ответом (31,5 \%).

Таблица 2

Как Вы относитесь к запрету религиозного течения ваххабизм в Российской Федерации? (в \%)

\begin{tabular}{|c|c|c|c|c|c|c|c|}
\hline \multirow{2}{*}{ 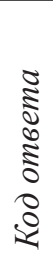 } & \multirow[b]{2}{*}{ Варианты ответа } & \multicolumn{2}{|c|}{ PA } & \multicolumn{2}{|c|}{ КБР } & \multicolumn{2}{|c|}{ КЧР } \\
\hline & & адыгейцы & $\begin{array}{c}\text { русские } \\
\text { и русско- } \\
\text { язычные }\end{array}$ & $\begin{array}{c}\text { кабар-динцы, } \\
\text { балкарцы }\end{array}$ & $\begin{array}{l}\text { русские } \\
\text { и русско- } \\
\text { язычные }\end{array}$ & $\begin{array}{c}\text { карача-евцы, } \\
\text { черкесы }\end{array}$ & $\begin{array}{c}\text { русские } \\
\text { и русско- } \\
\text { язычные }\end{array}$ \\
\hline 1 & $\begin{array}{l}\text { Безусловно } \\
\text { положительно }\end{array}$ & 24,7 & 59,6 & 52,1 & 48,8 & 52,1 & 58,7 \\
\hline
\end{tabular}

${ }^{4}$ Дзуцеев Х. В., Цуичиев А. А. Указ. соч. С. 23. 


\section{Национальная безопасность 1(24) • 2013}

\begin{tabular}{|c|l|l|l|l|l|l|l|}
\hline 2 & $\begin{array}{l}\text { Скорее } \\
\text { положительно }\end{array}$ & 16,4 & 7,1 & 10,1 & 14,4 & 9,6 & 7,6 \\
\hline 3 & $\begin{array}{l}\text { Нейтрально, } \\
\text { безразлично }\end{array}$ & 13,7 & 11,6 & 5,9 & 7,2 & 16,4 & 19,6 \\
\hline 4 & $\begin{array}{l}\text { Скорее } \\
\text { отрицательно }\end{array}$ & 5,5 & 2,0 & 7,1 & 5,6 & 4,1 & 1,1 \\
\hline 5 & $\begin{array}{l}\text { Безусловно } \\
\text { отрицательно }\end{array}$ & 8,2 & 7,1 & 5,9 & 7,2 & 4,1 & 3,3 \\
\hline $\begin{array}{l}\text { Затрудняюсь } \\
\text { ответить, отказ от }\end{array}$ & 31,5 & 12,6 & 18,9 & 16,8 & 13,7 & 9,8 \\
\hline & 100,0 & 100,0 & 100,0 & 100,0 & 100,0 & 100,0 \\
\hline
\end{tabular}

\begin{tabular}{|c|c|c|c|c|c|c|c|c|}
\hline \multirow{2}{*}{ 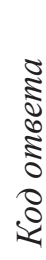 } & \multicolumn{2}{|c|}{ РД } & \multicolumn{2}{|c|}{ РИ } & \multicolumn{2}{|c|}{ PCO-A } & \multicolumn{2}{|c|}{ ЧР } \\
\hline & $\begin{array}{c}\text { народы } \\
\text { Дагестана }\end{array}$ & $\begin{array}{l}\text { русские } \\
\text { и русско- } \\
\text { язычные }\end{array}$ & ингуши & $\begin{array}{c}\text { русские } \\
\text { и русско- } \\
\text { язычные }\end{array}$ & осетины & $\begin{array}{l}\text { русские } \\
\text { и русско- } \\
\text { язычные }\end{array}$ & чеченцы & $\begin{array}{l}\text { русские } \\
\text { и русско- } \\
\text { язычные }\end{array}$ \\
\hline 1 & 65,9 & 55,8 & 39,3 & 50,0 & 53,6 & 74,7 & 62,9 & 67,5 \\
\hline 2 & 10,8 & 22,1 & 11,2 & 18,8 & 10,9 & 6,9 & 9,7 & 7,5 \\
\hline 3 & 3,0 & 2,9 & 15,0 & 6,3 & 4,7 & 6,9 & 8,1 & 8,8 \\
\hline 4 & 3,6 & 2,3 & 7,5 & 0,0 & 9,5 & 3,4 & 1,1 & 5,0 \\
\hline 5 & 5,4 & 4,1 & 9,3 & 6,3 & 7,1 & 4,6 & 2,2 & 5,0 \\
\hline 6 & 11,4 & 12,8 & 17,8 & 18,8 & 14,2 & 3,4 & 16,1 & 6,3 \\
\hline & 100,0 & 100,0 & 100,0 & 100,0 & 100,0 & 100,0 & 100,0 & 100,0 \\
\hline
\end{tabular}

Как видно из таблицы, подавляющее большинство респондентов выбрало варианты ответа «безусловно положительно» и «скорее положительно» на вопрос о запрете ваххабизма в РФ. Вполне единодушны респонденты в КБР, КЧР, РД, РИ, PCO-А, ЧР - у жителей региона ваххабизм ассоциируется с чеченской войной, поэтому подавляющее большинство респондентов склоняются к идее его запрета.
В обществе есть мнение: нужен жесткий контроль со стороны государства, которое должно проводить профилактические мероприятия. Необходимо предоставлять большую культурную и языковую автономию особенно сельским населенным пунктам, провинциальным городам. Человек всю жизнь может прожить, проработать в глубинке и ни разу не выехать в большой город. Надо дать людям возможность самовыражаться на родном языке, иметь свою 
прессу, словом, нужна коммуникация, а не изоляция, в результате которой противоречия загоняются вглубь и люди все больше замыкаются в себе. Они граждане нашей страны, и мы не можем от них просто откреститься. Запретами невозможно добиться результата, необходимо искать рациональный подход, чтобы не просто примирить одних с другими, с существующим бытом, а создать условия, в которых люди могли бы почувствовать себя комфортно, и тогда дискомфорт не приводил бы к агрессии.

Ваххабизм, по мнению экспертов, не всегда понимается правильно. Надо к этому подходить очень тонко, очень осторожно. Ваххабизм нельзя запрещать, надо разрешить его сторонникам действовать в качестве религиозной секты в пределах закона о деятельности религиозных сект. Это такое же религиозное течение, как и другие. Нужно, скорее просвещать, а не запрещать. Эксперты положительно относятся к запрету в нашей стране бандитизма и терроризма, но не надо называть это ваххабизмом.

Стоит больше уделять внимания не поискам «мифического» врага, а созданию условий по профилактике и предотвращению межрелигиозных распрей. Очень часто в РФ ярлык «ваххабит» навешивается на людей, не имеющих к нему никакого отношения.

Ответы респондентов в зависимости от гендерной принадлежности не носят существенных отличий, исключение составляет Адыгея, где коренное население мужского пола выбрало вариант «безусловно положительно» (таблица 2,1).

Таблицуа 2.1

Как Вы относитесь к запрету религиозного течения ваххабизм в Российской Федерации? (в \%)

\begin{tabular}{|c|c|c|c|c|c|c|c|c|c|}
\hline \multirow{3}{*}{ 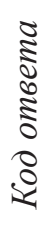 } & \multirow{3}{*}{ Варианты ответа } & \multicolumn{4}{|c|}{ PA } & \multicolumn{4}{|c|}{ КБР } \\
\hline & & \multicolumn{2}{|c|}{ адыгейцы } & \multicolumn{2}{|c|}{$\begin{array}{c}\text { русские и } \\
\text { русско-язычные }\end{array}$} & \multicolumn{2}{|c|}{$\begin{array}{c}\text { кабардинцы, } \\
\text { балкарцы }\end{array}$} & \multicolumn{2}{|c|}{$\begin{array}{c}\text { русские и } \\
\text { русско-язычные }\end{array}$} \\
\hline & & муж. & жен. & муж. & жен. & муж. & жен. & муж. & жен. \\
\hline 1 & $\begin{array}{l}\text { Безусловно } \\
\text { положительно }\end{array}$ & 19,4 & 28,6 & 55,8 & 62,5 & 53,8 & 49,4 & 50,9 & 46,3 \\
\hline 2 & Скорее положительно & 16,1 & 16,7 & 3,5 & 9,8 & 10,3 & 10,1 & 16,4 & 13,4 \\
\hline 3 & $\begin{array}{l}\text { Нейтрально, } \\
\text { безразлично }\end{array}$ & 16,1 & 11,9 & 17,4 & 7,1 & 6,4 & 5,6 & 10,9 & 4,5 \\
\hline 4 & Скорее отрицательно & 6,5 & 4,8 & 3,5 & 0,9 & 7,7 & 6,7 & 5,5 & 6,0 \\
\hline 5 & $\begin{array}{l}\text { Безусловно } \\
\text { отрицательно }\end{array}$ & 6,5 & 9,5 & 7,0 & 7,1 & 6,4 & 5,6 & 1,8 & 11,9 \\
\hline 6 & $\begin{array}{l}\text { Затрудняюсь } \\
\text { ответить, отказ от } \\
\text { ответа }\end{array}$ & 35,5 & 28,6 & 12,8 & 12,5 & 15,4 & 22,5 & 14,5 & 17,9 \\
\hline & & 100,0 & 100,0 & 100,0 & 100,0 & 100,0 & 100,0 & 100,0 & 100,0 \\
\hline
\end{tabular}

\begin{tabular}{|c|c|c|c|c|c|c|c|c|}
\hline \multirow{3}{*}{ 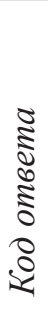 } & \multicolumn{4}{|c|}{ КЧР } & \multicolumn{4}{|c|}{ РД } \\
\hline & \multicolumn{2}{|c|}{ карачаевцы, черкесы } & \multicolumn{2}{|c|}{$\begin{array}{c}\text { русские и русско- } \\
\text { язычные }\end{array}$} & \multicolumn{2}{|c|}{ народы Дагестана } & \multicolumn{2}{|c|}{$\begin{array}{c}\text { русские и русско- } \\
\text { язычные }\end{array}$} \\
\hline & муж. & жен. & муж. & жен. & муж. & жен. & муж. & жен. \\
\hline 1 & 48,5 & 55,0 & 59,4 & 58,3 & 66,7 & 65,9 & 61,0 & 51,6 \\
\hline
\end{tabular}




\section{Национальная безопасность 1(24) • 2013}

\begin{tabular}{|c|c|c|c|c|c|c|c|c|}
\hline \multirow{3}{*}{ 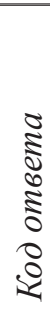 } & \multicolumn{4}{|c|}{ КЧР } & \multicolumn{4}{|c|}{ РД } \\
\hline & \multicolumn{2}{|c|}{ карачаевцы, черкесы } & \multicolumn{2}{|c|}{$\begin{array}{c}\text { русские и русско- } \\
\text { язычные }\end{array}$} & \multicolumn{2}{|c|}{ народы Дагестана } & \multicolumn{2}{|c|}{$\begin{array}{c}\text { русские и русско- } \\
\text { язычные }\end{array}$} \\
\hline & муж. & жен. & муж. & жен. & муж. & жен. & муж. & жен. \\
\hline 2 & 9,1 & 10,0 & 3,1 & 10,0 & 7,4 & 14,1 & 15,6 & 27,4 \\
\hline 3 & 24,2 & 10,0 & 21,9 & 18,3 & 6,2 & 0,0 & 2,6 & 3,2 \\
\hline 4 & 3,0 & 5,0 & 0,0 & 1,7 & 3,7 & 3,5 & 2,6 & 2,1 \\
\hline 5 & 6,1 & 2,5 & 6,3 & 1,7 & 6,2 & 3,5 & 3,9 & 4,2 \\
\hline 6 & 9,1 & 17,5 & 9,4 & 10,0 & 9,9 & 12,9 & 14,3 & 11,6 \\
\hline & 100,0 & 100,0 & 100,0 & 100,0 & 100,0 & 100,0 & 100,0 & 100,0 \\
\hline
\end{tabular}

\begin{tabular}{|c|c|c|c|c|c|c|c|c|c|c|c|c|}
\hline \multirow{3}{*}{ 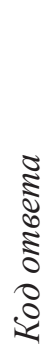 } & \multicolumn{4}{|c|}{ РИ } & \multicolumn{4}{|c|}{ PCO-A } & \multicolumn{4}{|c|}{ ЧР } \\
\hline & \multicolumn{2}{|c|}{ ингуши } & \multicolumn{2}{|c|}{$\begin{array}{c}\text { русские и рус- } \\
\text { скоязычные }\end{array}$} & \multicolumn{2}{|c|}{ осетины } & \multicolumn{2}{|c|}{$\begin{array}{c}\text { русские и рус- } \\
\text { скоязычные }\end{array}$} & \multicolumn{2}{|c|}{ чеченцы } & \multicolumn{2}{|c|}{$\begin{array}{c}\text { русские и рус } \\
\text { скоязычные }\end{array}$} \\
\hline & муж. & жен. & муж. & жен. & муж. & жен. & муж. & жен. & муж. & жен. & муж. & жен. \\
\hline 1 & 44,6 & 33,3 & 57,1 & 44,4 & 60,2 & 48,3 & 75,0 & 74,5 & 62,5 & 63,3 & 59,5 & 74,4 \\
\hline 2 & 8,9 & 13,7 & 0,0 & 33,3 & 10,8 & 11,0 & 0,0 & 11,8 & 10,2 & 9,2 & 10,8 & 4,7 \\
\hline 3 & 12,5 & 17,6 & 14,3 & 0,0 & 3,2 & 5,9 & 13,9 & 2,0 & 5,7 & 10,2 & 8,1 & 9,3 \\
\hline 4 & 8,9 & 5,9 & 0,0 & 0,0 & 9,7 & 9,3 & 5,6 & 2,0 & 1,1 & 1,0 & 5,4 & 4,7 \\
\hline 5 & 8,9 & 9,8 & 14,3 & 0,0 & 4,3 & 9,3 & 5,6 & 3,9 & 3,4 & 1,0 & 5,4 & 4,7 \\
\hline 6 & 16,1 & 19,6 & 14,3 & 22,2 & 11,8 & 16,1 & 0,0 & 5,9 & 17,0 & 15,3 & 10,8 & 2,3 \\
\hline & 100,0 & 100,0 & 100,0 & 100,0 & 100,0 & 100,0 & 100,0 & 100,0 & 100,0 & 100,0 & 100,0 & 100,0 \\
\hline
\end{tabular}

Как видно из таблицы 2.2, возраст респондента не является значимым фактором при выборе варианта ответа. Исключение - РА: вариант «безусловно положительно» выбрали 71,4 \% русских и русскоязыч- ных респондентов моложе 35 лет и 56,4 \% - старше 35 лет; в РИ этот вариант был предпочтительным для $60 \%$ русских и русскоязычных респондентов моложе 35 лет и 45,5 \% - старше 35 лет. 
Внутренние угрозы и контрмеры

Таблица 2.2

Как Вы относитесь к запрету религиозного течения ваххабизм в Российской Федерации? (в \%)

\begin{tabular}{|c|c|c|c|c|c|c|c|c|c|}
\hline \multirow{3}{*}{ 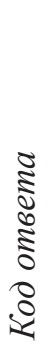 } & \multirow{3}{*}{ Варианты ответа } & \multicolumn{4}{|c|}{ PA } & \multicolumn{4}{|c|}{ КБР } \\
\hline & & \multicolumn{2}{|c|}{ адыгейцы } & \multicolumn{2}{|c|}{$\begin{array}{l}\text { русские и рус- } \\
\text { скоязычные }\end{array}$} & \multicolumn{2}{|c|}{$\begin{array}{c}\text { кабардинцы, } \\
\text { балкарцы }\end{array}$} & \multicolumn{2}{|c|}{$\begin{array}{l}\text { русские и рус- } \\
\text { скоязычные }\end{array}$} \\
\hline & & $\begin{array}{c}\text { до } \\
35 \text { лет }\end{array}$ & $\begin{array}{l}\text { старше } \\
35 \text { лет }\end{array}$ & $\begin{array}{c}\text { до } \\
35 \text { лет }\end{array}$ & $\begin{array}{l}\text { старше } \\
35 \text { лет }\end{array}$ & $\begin{array}{c}\text { до } \\
35 \text { лет }\end{array}$ & $\begin{array}{l}\text { старше } \\
35 \text { лет }\end{array}$ & $\begin{array}{c}\text { до } \\
35 \text { лет }\end{array}$ & $\begin{array}{l}\text { старше } \\
35 \text { лет }\end{array}$ \\
\hline 1 & Безусловно положительно & 29,2 & 22,4 & 71,4 & 56,4 & 48,6 & 54,5 & 50,0 & 48,4 \\
\hline 2 & Скорее положительно & 16,7 & 16,3 & 2,4 & 8,3 & 10,0 & 10,1 & 20,0 & 12,6 \\
\hline 3 & Нейтрально, безразлично & 12,5 & 14,3 & 4,8 & 13,5 & 10,0 & 3,0 & 10,0 & 6,3 \\
\hline 4 & Скорее отрицательно & 12,5 & 2,0 & 2,4 & 1,9 & 4,3 & 9,1 & 0,0 & 7,4 \\
\hline 5 & Безусловно отрицательно & 4,2 & 10,2 & 7,1 & 7,1 & 8,6 & 4,0 & 10,0 & 6,3 \\
\hline 6 & $\begin{array}{l}\text { Затрудняюсь ответить, } \\
\text { отказ от ответа }\end{array}$ & 25,0 & 34,7 & 11,9 & 12,8 & 18,6 & 19,2 & 10,0 & 18,9 \\
\hline & & 100,0 & 100,0 & 100,0 & 100,0 & 100,0 & 100,0 & 100,0 & 100,0 \\
\hline
\end{tabular}

\begin{tabular}{|c|c|c|c|c|c|c|c|c|}
\hline \multirow{3}{*}{ 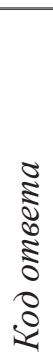 } & \multicolumn{4}{|c|}{ КЧР } & \multicolumn{4}{|c|}{ РД } \\
\hline & \multicolumn{2}{|c|}{ карачаевцы, черкесы } & \multicolumn{2}{|c|}{$\begin{array}{c}\text { русские и русско- } \\
\text { язычные }\end{array}$} & \multicolumn{2}{|c|}{ народы Дагестана } & \multicolumn{2}{|c|}{$\begin{array}{c}\text { русские и русско- } \\
\text { язычные }\end{array}$} \\
\hline & до 35 лет & $\begin{array}{l}\text { старше } \\
35 \text { лет }\end{array}$ & до 35 лет & $\begin{array}{l}\text { старше } \\
35 \text { лет }\end{array}$ & до 35 лет & $\begin{array}{c}\text { старше } \\
35 \text { лет }\end{array}$ & до 35 лет & $\begin{array}{l}\text { старше } \\
35 \text { лет }\end{array}$ \\
\hline 1 & 54,7 & 45,0 & 55,6 & 60,0 & 66,2 & 65,7 & 54,5 & 56,0 \\
\hline 2 & 7,5 & 15,0 & 11,1 & 6,2 & 5,9 & 14,1 & 22,7 & 22,0 \\
\hline 3 & 15,1 & 20,0 & 14,8 & 21,5 & 4,4 & 2,0 & 4,5 & 2,7 \\
\hline 4 & 5,7 & 0,0 & 0,0 & 1,5 & 7,4 & 1,0 & 4,5 & 2,0 \\
\hline 5 & 1,9 & 10,0 & 3,7 & 3,1 & 4,4 & 6,1 & 4,5 & 4,0 \\
\hline 6 & 15,1 & 10,0 & 14,8 & 7,7 & 11,8 & 11,1 & 9,1 & 13,3 \\
\hline & 100,0 & 100,0 & 100,0 & 100,0 & 100,0 & 100,0 & 100,0 & 100,0 \\
\hline
\end{tabular}




\section{Национальная безопасность 1(24) • 2013}

\begin{tabular}{|c|c|c|c|c|c|c|c|c|c|c|c|c|}
\hline \multirow{3}{*}{ 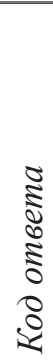 } & \multicolumn{4}{|c|}{ РИ } & \multicolumn{4}{|c|}{ PCO-A } & \multicolumn{4}{|c|}{ ЧР } \\
\hline & \multicolumn{2}{|c|}{ ингуши } & \multicolumn{2}{|c|}{$\begin{array}{c}\text { русские и } \\
\text { русскоязычные }\end{array}$} & \multicolumn{2}{|c|}{ осетины } & \multicolumn{2}{|c|}{$\begin{array}{c}\text { русские и } \\
\text { русскоязычные }\end{array}$} & \multicolumn{2}{|c|}{ чеченцы } & \multicolumn{2}{|c|}{$\begin{array}{c}\text { русские и } \\
\text { русскоязычные }\end{array}$} \\
\hline & $\begin{array}{c}\text { до } \\
35 \text { лет }\end{array}$ & $\begin{array}{c}\text { старше } \\
35 \text { лет }\end{array}$ & $\begin{array}{c}\text { до } \\
35 \text { лет }\end{array}$ & $\begin{array}{l}\text { старше } \\
35 \text { лет }\end{array}$ & $\begin{array}{c}\text { до } \\
35 \text { лет }\end{array}$ & $\begin{array}{l}\text { старше } \\
35 \text { лет }\end{array}$ & $\begin{array}{c}\text { до } \\
35 \text { лет }\end{array}$ & $\begin{array}{c}\text { старше } \\
35 \text { лет }\end{array}$ & $\begin{array}{c}\text { до } \\
35 \text { лет }\end{array}$ & $\begin{array}{l}\text { старше } \\
35 \text { лет }\end{array}$ & $\begin{array}{c}\text { до } \\
35 \text { лет }\end{array}$ & $\begin{array}{c}\text { старше } \\
35 \text { лет }\end{array}$ \\
\hline 1 & 41,2 & 37,5 & 60,0 & 45,5 & 55,4 & 51,8 & 70,0 & 77,2 & 51,5 & 69,5 & 72,4 & 64,7 \\
\hline 2 & 13,7 & 8,9 & 20,0 & 18,2 & 9,9 & 11,8 & 6,7 & 7,0 & 10,3 & 9,3 & 10,3 & 5,9 \\
\hline 3 & 15,7 & 14,3 & 20,0 & 0,0 & 2,0 & 7,3 & 6,7 & 7,0 & 8,8 & 7,6 & 3,4 & 11,8 \\
\hline 4 & 2,0 & 12,5 & 0,0 & 0,0 & 9,9 & 9,1 & 3,3 & 3,5 & 0,0 & 1,7 & 3,4 & 5,9 \\
\hline 5 & 3,9 & 14,3 & 0,0 & 9,1 & 9,9 & 4,5 & 3,3 & 5,3 & 4,4 & 0,8 & 3,4 & 5,9 \\
\hline 6 & 23,5 & 12,5 & 0,0 & 27,3 & 12,9 & 15,5 & 10,0 & 0,0 & 25,0 & 11,0 & 6,9 & 5,9 \\
\hline & 100,0 & 100,0 & 100,0 & 100,0 & 100,0 & 100,0 & 100,0 & 100,0 & 100,0 & 100,0 & 100,0 & 100,0 \\
\hline
\end{tabular}

Уровень образования респондентов, как показал опрос, также не является значимым фактором при выборе варианта ответа (таблица 2.3).

Таблииа 2.3

Как Вы относитесь к запрету религиозного течения ваххабизм в Российской Федерации? (в \%)

\begin{tabular}{|c|c|c|c|c|c|c|c|c|c|}
\hline \multirow{3}{*}{$\begin{array}{l}\widetilde{I} \\
\mathbb{8}\end{array}$} & \multirow{3}{*}{ Варианты ответа } & \multicolumn{4}{|c|}{ PA } & \multicolumn{4}{|c|}{ КБР } \\
\hline & & \multicolumn{2}{|c|}{ адыгейцы } & \multicolumn{2}{|c|}{$\begin{array}{c}\text { русские и } \\
\text { русскоязычные }\end{array}$} & \multicolumn{2}{|c|}{$\begin{array}{c}\text { кабардинцы, } \\
\text { балкарцы }\end{array}$} & \multicolumn{2}{|c|}{$\begin{array}{c}\text { русские и } \\
\text { русскоязычные }\end{array}$} \\
\hline & & $\begin{array}{c}\text { ср. } \\
\text { спец. и } \\
\text { ниже }\end{array}$ & $\begin{array}{c}\text { н/в, } \\
\text { высшее }\end{array}$ & $\begin{array}{c}\text { ср. } \\
\text { спец. и } \\
\text { ниже }\end{array}$ & $\begin{array}{c}\text { н/в, } \\
\text { высшее }\end{array}$ & $\begin{array}{c}\text { ср. } \\
\text { спец. и } \\
\text { ниже }\end{array}$ & $\begin{array}{c}\text { н/в, } \\
\text { высшее }\end{array}$ & $\begin{array}{c}\text { ср. } \\
\text { спец. и } \\
\text { ниже }\end{array}$ & $\begin{array}{c}\text { н/в, } \\
\text { высшее }\end{array}$ \\
\hline 1 & Безусловно положительно & 16,7 & 40,0 & 52,4 & 76,5 & 65,7 & 55,1 & 37,5 & 60,4 \\
\hline 2 & Скорее положительно & 16,7 & 16,0 & 7,0 & 7,8 & 17,1 & 8,2 & 18,8 & 5,7 \\
\hline 3 & Нейтрально, безразлично & 14,6 & 12,0 & 14,7 & 3,9 & 0,0 & 8,2 & 8,3 & 5,7 \\
\hline 4 & Скорее отрицательно & 4,2 & 8,0 & 2,8 & 0,0 & 11,4 & 4,1 & 10,4 & 1,9 \\
\hline 5 & Безусловно отрицательно & 10,4 & 4,0 & 7,7 & 5,9 & 0,0 & 4,1 & 8,3 & 5,7 \\
\hline
\end{tabular}


Внутренние угрозы и контрмеры

\begin{tabular}{|c|c|c|c|c|c|c|c|c|c|}
\hline \multirow[b]{3}{*}{$\begin{array}{l}\Xi \\
\Xi \\
\Xi \\
\Xi \\
0 \\
0 \\
8 \\
0\end{array}$} & \multirow{3}{*}{ Варианты ответа } & \multicolumn{4}{|c|}{$\mathrm{PA}$} & \multicolumn{4}{|c|}{ КБР } \\
\hline & & \multicolumn{2}{|c|}{ адыгейцы } & \multicolumn{2}{|c|}{$\begin{array}{c}\text { русские и } \\
\text { русскоязычные }\end{array}$} & \multicolumn{2}{|c|}{$\begin{array}{c}\text { кабардинцы, } \\
\text { балкарцы }\end{array}$} & \multicolumn{2}{|c|}{$\begin{array}{c}\text { русские и } \\
\text { русскоязычные }\end{array}$} \\
\hline & & $\begin{array}{c}\text { ср. } \\
\text { спец. и } \\
\text { ниже }\end{array}$ & $\begin{array}{c}\text { н/в, } \\
\text { высшее }\end{array}$ & $\begin{array}{c}\text { ср. } \\
\text { спец. и } \\
\text { ниже }\end{array}$ & $\begin{array}{c}\text { н/в, } \\
\text { высшее }\end{array}$ & $\begin{array}{c}\text { ср. } \\
\text { спец. и } \\
\text { ниже }\end{array}$ & $\begin{array}{c}\text { н/в, } \\
\text { высшее }\end{array}$ & $\begin{array}{c}\text { ср. } \\
\text { спец. и } \\
\text { ниже }\end{array}$ & $\begin{array}{c}\text { н/в, } \\
\text { высшее }\end{array}$ \\
\hline 6 & $\begin{array}{l}\text { Затрудняюсь ответить, } \\
\text { отказ от ответа }\end{array}$ & 37,5 & 20,0 & 15,4 & 5,9 & 5,7 & 20,4 & 16,7 & 20,8 \\
\hline & & 100,0 & 100,0 & 100,0 & 100,0 & 100,0 & 100,0 & 100,0 & 100,0 \\
\hline
\end{tabular}

\begin{tabular}{|c|c|c|c|c|c|c|c|c|}
\hline \multirow{3}{*}{ 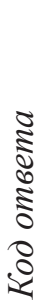 } & \multicolumn{4}{|c|}{ КЧР } & \multicolumn{4}{|c|}{ РД } \\
\hline & \multicolumn{2}{|c|}{ карачаевцы, черкесы } & \multicolumn{2}{|c|}{$\begin{array}{c}\text { русские и русско- } \\
\text { язычные }\end{array}$} & \multicolumn{2}{|c|}{ народы Дагестана } & \multicolumn{2}{|c|}{$\begin{array}{c}\text { русские и русско- } \\
\text { язычные }\end{array}$} \\
\hline & $\begin{array}{l}\text { ср. спец. и } \\
\text { ниже }\end{array}$ & $\begin{array}{c}\text { н/в, } \\
\text { высшее }\end{array}$ & $\begin{array}{l}\text { ср. спец. и } \\
\text { ниже }\end{array}$ & $\begin{array}{c}\text { н/в, } \\
\text { высшее }\end{array}$ & $\begin{array}{l}\text { ср. спец. и } \\
\text { ниже }\end{array}$ & $\begin{array}{c}\text { н/в, } \\
\text { высшее }\end{array}$ & $\begin{array}{l}\text { ср. спец. и } \\
\text { ниже }\end{array}$ & $\begin{array}{c}\text { н/в, } \\
\text { высшее }\end{array}$ \\
\hline 1 & 61,1 & 49,1 & 57,6 & 64,5 & 73,5 & 55,2 & 57,9 & 50,9 \\
\hline 2 & 5,6 & 10,9 & 8,5 & 6,5 & 7,1 & 16,4 & 25,4 & 15,8 \\
\hline 3 & 22,2 & 14,5 & 23,7 & 9,7 & 1,0 & 6,0 & 2,6 & 3,5 \\
\hline 4 & 0,0 & 5,5 & 0,0 & 3,2 & 3,1 & 4,5 & 1,8 & 3,5 \\
\hline 5 & 0,0 & 5,5 & 3,4 & 0,0 & 4,1 & 6,0 & 1,8 & 8,8 \\
\hline 6 & 11,1 & 14,5 & 6,8 & 16,1 & 11,2 & 11,9 & 10,5 & 17,5 \\
\hline & 100,0 & 100,0 & 100,0 & 100,0 & 100,0 & 100,0 & 100,0 & 100,0 \\
\hline
\end{tabular}

\begin{tabular}{|c|c|c|c|c|c|c|c|c|c|c|c|c|}
\hline \multirow[b]{3}{*}{ 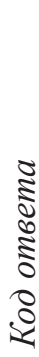 } & \multicolumn{4}{|c|}{ РИ } & \multicolumn{4}{|c|}{ PCO-A } & \multicolumn{4}{|c|}{ ЧР } \\
\hline & \multicolumn{2}{|c|}{ ингуши } & \multicolumn{2}{|c|}{$\begin{array}{c}\text { русские и рус- } \\
\text { скоязычные }\end{array}$} & \multicolumn{2}{|c|}{ осетины } & \multicolumn{2}{|c|}{$\begin{array}{c}\text { русские и рус- } \\
\text { скоязычные }\end{array}$} & \multicolumn{2}{|c|}{ чеченцы } & \multicolumn{2}{|c|}{$\begin{array}{c}\text { русские и рус- } \\
\text { скоязычные }\end{array}$} \\
\hline & $\begin{array}{c}\text { ср. } \\
\text { спец. и } \\
\text { ниже }\end{array}$ & $\begin{array}{l}\text { н/в, } \\
\text { выс- } \\
\text { шеe }\end{array}$ & $\begin{array}{c}\text { ср. } \\
\text { спец. и } \\
\text { ниже }\end{array}$ & $\begin{array}{c}\text { н/в, } \\
\text { выс- } \\
\text { шеe }\end{array}$ & $\begin{array}{c}\text { ср. } \\
\text { спец. и } \\
\text { ниже }\end{array}$ & $\begin{array}{l}\text { н/в, } \\
\text { выс- } \\
\text { шее }\end{array}$ & $\begin{array}{c}\text { сp. } \\
\text { спец. и } \\
\text { ниже }\end{array}$ & $\begin{array}{c}\text { н/в, } \\
\text { выс- } \\
\text { шеe }\end{array}$ & $\begin{array}{c}\text { ср. } \\
\text { спец. и } \\
\text { ниже }\end{array}$ & $\begin{array}{l}\text { н/в, } \\
\text { выс- } \\
\text { шеe }\end{array}$ & $\begin{array}{c}\text { сp. } \\
\text { спец. и } \\
\text { ниже }\end{array}$ & $\begin{array}{c}\text { н/в, } \\
\text { выс- } \\
\text { шеe }\end{array}$ \\
\hline 1 & 40,7 & 39,5 & 28,6 & 62,5 & 50,0 & 56,2 & 60,6 & 83,3 & 67,2 & 53,2 & 63,2 & 77,3 \\
\hline 2 & 8,5 & 16,3 & 42,9 & 0,0 & 12,8 & 9,9 & 12,1 & 3,7 & 10,7 & 8,1 & 10,5 & 0,0 \\
\hline
\end{tabular}




\section{Национальная безопасность $1(24) \cdot 2013$}

\begin{tabular}{|c|c|c|c|c|c|c|c|c|c|c|c|c|}
\hline \multirow[b]{3}{*}{ 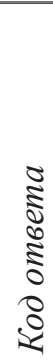 } & \multicolumn{4}{|c|}{ РИ } & \multicolumn{4}{|c|}{ PCO-A } & \multicolumn{4}{|c|}{ ЧР } \\
\hline & \multicolumn{2}{|c|}{ ингуши } & \multicolumn{2}{|c|}{$\begin{array}{c}\text { русские и рус- } \\
\text { скоязычные }\end{array}$} & \multicolumn{2}{|c|}{ осетины } & \multicolumn{2}{|c|}{$\begin{array}{l}\text { русские и рус- } \\
\text { скоязычные }\end{array}$} & \multicolumn{2}{|c|}{ чеченцы } & \multicolumn{2}{|c|}{$\begin{array}{c}\text { русские и рус- } \\
\text { скоязычные }\end{array}$} \\
\hline & $\begin{array}{c}\text { ср. } \\
\text { спец. и } \\
\text { ниже }\end{array}$ & $\begin{array}{l}\text { н/в, } \\
\text { выс- } \\
\text { шее }\end{array}$ & $\begin{array}{c}\text { сp. } \\
\text { спец. и } \\
\text { ниже }\end{array}$ & $\begin{array}{l}\text { н/в, } \\
\text { выс- } \\
\text { шее }\end{array}$ & $\begin{array}{c}\text { ср. } \\
\text { спец. и } \\
\text { ниже }\end{array}$ & $\begin{array}{l}\text { н/в, } \\
\text { выс- } \\
\text { шее }\end{array}$ & $\begin{array}{c}\text { сp. } \\
\text { спец. и } \\
\text { ниже }\end{array}$ & $\begin{array}{l}\text { н/в, } \\
\text { выс- } \\
\text { шеe }\end{array}$ & $\begin{array}{c}\text { ср. } \\
\text { спец. и } \\
\text { ниже }\end{array}$ & $\begin{array}{l}\text { н/в, } \\
\text { выс- } \\
\text { шеe }\end{array}$ & $\begin{array}{c}\text { ср. } \\
\text { спец. и } \\
\text { ниже }\end{array}$ & $\begin{array}{l}\text { н/в, } \\
\text { выс- } \\
\text { шеe }\end{array}$ \\
\hline 3 & 13,6 & 11,6 & 0,0 & 12,5 & 3,5 & 5,0 & 9,1 & 5,6 & 5,7 & 12,9 & 10,5 & 4,5 \\
\hline 4 & 8,5 & 4,7 & 0,0 & 0,0 & 12,8 & 7,4 & 6,1 & 1,9 & 0,8 & 1,6 & 7,0 & 0,0 \\
\hline 5 & 10,2 & 9,3 & 0,0 & 12,5 & 8,1 & 5,8 & 6,1 & 3,7 & 1,6 & 3,2 & 3,5 & 9,1 \\
\hline 6 & 18,6 & 18,6 & 28,6 & 12,5 & 12,8 & 15,7 & 6,1 & 1,9 & 13,9 & 21,0 & 5,3 & 9,1 \\
\hline & 100,0 & 100,0 & 100,0 & 100,0 & 100,0 & 100,0 & 100,0 & 100,0 & 100,0 & 100,0 & 100,0 & 100,0 \\
\hline
\end{tabular}

Всего лишь 16,7 \% адыгейцев со средним специальным образованием «безусловно положительно» относятся к запрету ваххабизма. Больше всего сторонников запрета ваххабизма - 83,3 \% среди русских и русскоязычных РСО-А (вариант «безусловно положительно»).

Анализ материалов таблицы позволяет сделать следующие выводы. В своем подавляющем большинстве респонденты из обеих образовательных групп, но в особенности те, кто имеет незаконченное высшее и высшее образование, против запрета ваххабизма.

Обществу, по мнению экспертов, нужны не запретные меры, а большая разъяснительная работа. Запрещать какое-либо религиозное течение необходимо в тех случаях, когда его сторонники связаны с крайним экстремизмом, если оно несет с собой агрессию, демонстрирует неприятие других конфессий. Среди экспертов есть и такие, кто не считает ваххабизм синонимом терроризма, а рассматривает его лишь как государственную религию Саудовской Аравии.
Эксперты считают, что должен быть принят закон, запрещающий экстремистские течения как политические, так и религиозные. Поскольку в России мы имеем дело с радикальной формой ваххабизма и многие террористические акты были связаны с ваххабитами, то, естественно, сформировался негативный имидж ваххабизма. Для далекого от ислама человека важным является и то, какие политические действия связаны с ваххабитами. Пока же на Северном Кавказе ваххабизм проявил себя крайне негативно, российские ваххабиты запятнали себя участием в террористических актах.

Анализ ответов респондентов в зависимости от типа населенного пункта показал, что никто из городских русских и русскоязычных жителей ЧР не относится к запрету ваххабизма в РФ «скорее положительно» и «нейтрально». В РСО-А никто не выбрал вариант «нейтрально» и «скорее отрицательно» (таблица 2.4).

Таблица 2.4

Как Вы относитесь к запрету религиозного течения ваххабизм в Российской Федерации? (в \%)

\begin{tabular}{|c|c|c|c|c|c|c|c|c|c|}
\hline \multirow{3}{*}{ 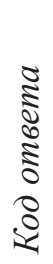 } & \multirow{3}{*}{ Варианты ответа } & \multicolumn{4}{|c|}{ PA } & \multicolumn{4}{|c|}{ КБР } \\
\hline & & \multicolumn{2}{|c|}{ адыгейцы } & \multicolumn{2}{|c|}{$\begin{array}{c}\text { русские и рус- } \\
\text { скоязычные }\end{array}$} & \multicolumn{2}{|c|}{$\begin{array}{c}\text { кабардинцы, } \\
\text { балкарцы }\end{array}$} & \multicolumn{2}{|c|}{$\begin{array}{c}\text { русские и рус- } \\
\text { скоязычные }\end{array}$} \\
\hline & & город & село & город & село & город & село & город & село \\
\hline 1 & Безусловно положительно & 31,0 & 20,5 & 64,1 & 54,7 & 45,7 & 56 & 49,5 & 48,1 \\
\hline 2 & Скорее положительно & 20,7 & 13,6 & 7,8 & 6,3 & 8,6 & 11,2 & 14,4 & 11,1 \\
\hline
\end{tabular}


Внутренние угрозы и контрмеры

\begin{tabular}{|c|c|c|c|c|c|c|c|c|c|}
\hline \multirow{3}{*}{ 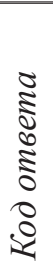 } & \multirow{3}{*}{ Варианты ответа } & \multicolumn{4}{|c|}{$\mathrm{PA}$} & \multicolumn{4}{|c|}{ КБР } \\
\hline & & \multicolumn{2}{|c|}{ адыгейцы } & \multicolumn{2}{|c|}{$\begin{array}{l}\text { русские и рус- } \\
\text { скоязычные }\end{array}$} & \multicolumn{2}{|c|}{$\begin{array}{c}\text { кабардинцы, } \\
\text { балкарцы }\end{array}$} & \multicolumn{2}{|c|}{$\begin{array}{c}\text { русские и рус- } \\
\text { скоязычные }\end{array}$} \\
\hline & & город & село & город & село & город & село & город & село \\
\hline 3 & Нейтрально, безразлично & 10,3 & 15,9 & 8,7 & 14,7 & 10,0 & 3,1 & 6,2 & 11,1 \\
\hline 4 & Скорее отрицательно & 3,4 & 6,8 & 1,0 & 3,2 & 7,1 & 7,1 & 4,1 & 11,1 \\
\hline 5 & Безусловно отрицательно & 3,4 & 11,4 & 3,9 & 10,5 & 7,1 & 5,1 & 6,2 & 11,1 \\
\hline 6 & $\begin{array}{l}\text { Затрудняюсь ответить, } \\
\text { отказ от ответа }\end{array}$ & 31,0 & 31,8 & 14,6 & 10,5 & 21,4 & 17,3 & 19,6 & 7,4 \\
\hline & & 100,0 & 100,0 & 100,0 & 100,0 & 100,0 & 100,0 & 100,0 & 100,0 \\
\hline
\end{tabular}

\begin{tabular}{|c|c|c|c|c|c|c|c|c|}
\hline \multirow{3}{*}{ 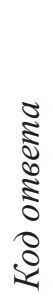 } & \multicolumn{4}{|c|}{ КЧР } & \multicolumn{4}{|c|}{ РД } \\
\hline & \multicolumn{2}{|c|}{ карачаевцы, черкесы } & \multicolumn{2}{|c|}{$\begin{array}{c}\text { русские и русско- } \\
\text { язычные }\end{array}$} & \multicolumn{2}{|c|}{ народы Дагестана } & \multicolumn{2}{|c|}{$\begin{array}{c}\text { русские и русско- } \\
\text { язычные }\end{array}$} \\
\hline & город & село & город & село & город & село & город & село \\
\hline 1 & 54,8 & 48,4 & 63,6 & 51,4 & 60,8 & 70,5 & 58,7 & 52,5 \\
\hline 2 & 9,5 & 9,7 & 7,3 & 8,1 & 12,7 & 9,1 & 9,8 & 36,3 \\
\hline 3 & 14,3 & 19,4 & 14,5 & 27,0 & 5,1 & 1,1 & 3,3 & 2,5 \\
\hline 4 & 7,1 & 0,0 & 1,8 & 0,0 & 3,8 & 3,4 & 2,2 & 2,5 \\
\hline 5 & 2,4 & 6,5 & 1,8 & 5,4 & 3,8 & 6,8 & 6,5 & 1,3 \\
\hline 6 & 11,9 & 16,1 & 10,9 & 8,1 & 13,9 & 9,1 & 19,6 & 5,0 \\
\hline & 100,0 & 100,0 & 100,0 & 100,0 & 100,0 & 100,0 & 100,0 & 100,0 \\
\hline
\end{tabular}

\begin{tabular}{|c|c|c|c|c|c|c|c|c|c|c|c|c|}
\hline \multirow{3}{*}{ 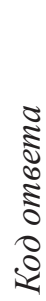 } & \multicolumn{4}{|c|}{ РИ } & \multicolumn{4}{|c|}{ PCO-A } & \multicolumn{4}{|c|}{ ЧР } \\
\hline & \multicolumn{2}{|c|}{ ингуши } & \multicolumn{2}{|c|}{$\begin{array}{c}\text { русские и } \\
\text { русскоязычные }\end{array}$} & \multicolumn{2}{|c|}{ осетины } & \multicolumn{2}{|c|}{$\begin{array}{c}\text { русские и } \\
\text { русскоязычные }\end{array}$} & \multicolumn{2}{|c|}{ чеченцы } & \multicolumn{2}{|c|}{$\begin{array}{c}\text { русские и } \\
\text { русскоязычные }\end{array}$} \\
\hline & город & село & город & село & город & село & город & село & город & село & город & село \\
\hline 1 & 36,4 & 43,9 & 45,5 & 60,0 & 56,9 & 49,5 & 75,7 & 70,6 & 48,8 & 74,5 & 66,7 & 67,7 \\
\hline
\end{tabular}




\section{Национальная безопасность 1(24) • 2013}

\begin{tabular}{|c|c|c|c|c|c|c|c|c|c|c|c|c|}
\hline \multirow{3}{*}{ 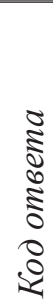 } & \multicolumn{4}{|c|}{ РИ } & \multicolumn{4}{|c|}{ PCO-A } & \multicolumn{4}{|c|}{ ЧР } \\
\hline & \multicolumn{2}{|c|}{ ингуши } & \multicolumn{2}{|c|}{$\begin{array}{c}\text { русские и } \\
\text { русскоязычные }\end{array}$} & \multicolumn{2}{|c|}{ осетины } & \multicolumn{2}{|c|}{$\begin{array}{c}\text { русские и } \\
\text { русскоязычные }\end{array}$} & \multicolumn{2}{|c|}{ чеченцы } & \multicolumn{2}{|c|}{$\begin{array}{c}\text { русские и } \\
\text { русскоязычные }\end{array}$} \\
\hline & город & село & город & село & город & село & город & село & город & село & город & село \\
\hline 2 & 6,1 & 19,5 & 9,1 & 40,0 & 12,9 & 8,4 & 5,7 & 11,8 & 11,9 & 7,8 & 0,0 & 9,2 \\
\hline 3 & 15,2 & 14,6 & 9,1 & 0,0 & 6,0 & 3,2 & 8,6 & 0,0 & 10,7 & 5,9 & 0,0 & 10,8 \\
\hline 4 & 7,6 & 7,3 & 0,0 & 0,0 & 6,0 & 13,7 & 4,3 & 0,0 & 1,2 & 1,0 & 6,7 & 4,6 \\
\hline 5 & 15,2 & 0,0 & 9,1 & 0,0 & 6,9 & 7,4 & 4,3 & 5,9 & 3,6 & 1,0 & 13,3 & 3,1 \\
\hline 6 & 19,7 & 14,6 & 27,3 & 0,0 & 11,2 & 17,9 & 1,4 & 11,8 & 23,8 & 9,8 & 13,3 & 4,6 \\
\hline & 100,0 & 100,0 & 100,0 & 100,0 & 100,0 & 100,0 & 100,0 & 100,0 & 100,0 & 100,0 & 100,0 & 100,0 \\
\hline
\end{tabular}

В системе политического менеджмента и прогнозирования мы считаем важным выяснить отношение населения республик СКФО к шариату 5 . Шариат и вообще религия мусульманства предполагают полную идентичность образа жизни и моральных норм Корану. С историко-социологической точки зрения шариат можно понимать как учение об исламском образе жизни, представляющее комплекс обязательных религиозно-правовых предписаний и норм, основанных на Коране и Сунне. Традиционные мусульманские государства пока не сформировали классическую государственность, это видно на примере Пакистана, Ирана. Очевидно, государство - само по себе, образ жизни людей - сам по себе, поэтому народные массы в этих странах больше живут на общинном уровне. И поскольку социальную жизнь надо регулировать на основе каких-то традиционных норм, обществу в этом качестве предлагается Коран. Он называется законом, но это не закон это обязательное соблюдение принципов морали и нравственности. Поэтому все везде управляется Кораном, независимо от того, консервативно это или нет. Разрушить такое невозможно. И, конечно,

5 Шариат (араб. ат-шари'а - ясный, правильный путь; закон, обязательные предписания) - совокупность предписаний, основанных на Коране и Сунне, определяющих нравственные ценности и нормы поведения мусульман // Социологическая энциклопедия. Т. II. М., 2003. С. 772. мораль не может заменить закон. Это противоречие у мусульман - в общинном образе жизни.

Это специфика не только мусульман, то же самое происходит и в Японии. С одной стороны, цивилизованные государственные структуры, с другой рабовладельческая мораль в бытовых отношениях, включая семью. Отсюда и стрессы, и самый высокий в мире показатель по самоубийствам. В какой-то мере мы можем провести какие-то параллели и на Северном Кавказе. Так, например, Чечня существует в светском государстве, но она полностью изолирована и живет по своим канонам, то есть житель этой республики ни сознанием, ни идеологией не вписывается в Россию, в светское государство. Гражданское поведение населения является чистой имитацией, надо пойти на выборы - идет 99 \% населения. Народ не трогает избирательная система. Для него выборы - это все равно, что кому-то поклониться или кого-то поприветствовать. Люди голосуют для России. Но их жизнь это голосование абсолютно не затронуло, а если бы затронуло, они не пошли бы голосовать. Но так как к их жизни эти выборы отношения не имеют, тогда какая им разница? В конце концов это их Государственная дума, пусть она и думает. А при малейшем кризисе в России они начнут замыкаться и проявлять склонность к сепаратизму, потому что к светскому государству они не захотят адаптироваться. А кризис может возникнуть в любой момент. Система кастовая, и, если с нынешним руководством Чечни по вине внешних сил что-то слу- 
Внутренние угрозы и контрмеры

чится, начнется вторая гражданская война, потому что произойдет дележ власти (здесь есть нефть, есть деньги). Население это чувствует и все, что связано с шариатским государством, отвергает, понимая, что это принесет им дополнительные социальные проблемы. Эта картина хорошо просматривается на материалах наших исследований.

На вопрос «Лично Вы хотели бы жить в светском или шариатском государстве?» ответили «безусловно в светском государстве» следующие группы респондентов: $75,9 \%$ русских и русскоязычных в РД, 67,3 \% русских и русскоязычных в РА, 62,1 \% русских и русскоязычных в РСО-А, 58 \% русских и русскоязычных в ЧР, 50,5 \% русских и русскоязычных в КЧР, 49,4 \% народов Дагестана, 49,3 \% осетин, 44 \% адыгейцев, 32,7 \% кабардинцев, балкарцев, 30,2 \% русских и русскоязычных в КБР, 27 \% карачаевцев, черкесов, 22,2 \% русских и русскоязычных в РИ, 19,5 \% чеченцев, 8,9 \% ингушей (таблица 3).

«Скорее в светском государстве» хотели бы жить: 28,9 \% чеченцев, $27 \%$ русских и русскоязычных в КБР, 22,8 \% кабардинцев, балкарцев, 22,6 \% адыгейцев, 22,3\% осетин, $21 \%$ русских и русскоязычных ЧР, 19,4 \% русских и русскоязычных РА, 17,6 \% ка- рачаевцев, черкесов, 17 \% ингушей, 14,9 \% русских и русскоязычных в РСО-А, 14,5 \% представителей коренных народов Дагестана, 12,6 \% русских и русскоязычных в КЧР, 11,5 \% русских и русскоязычных в РД, 5,6 \% русских и русскоязычных в РИ.

По третьему и четвертому вариантам — «скорее в шариатском государстве» и «безусловно в шариатском государстве» ни одна из групп не набрала легитимного большинства, кроме русских и русскоязычных в РИ: 27,8 \% респондентов - жителей этой республики хотели бы жить «безусловно в шариатском государстве».

Относительно высок процент затруднившихся с ответом или отказавшихся отвечать на данный вопрос: 33,9 \% кабардинцев, балкарцев, 32,5 \% русских и русскоязычных в КБР, 27,8 \% русских и русскоязычных в РИ, 27,4 \% адыгейцев, 26,8 \% ингушей, 25,3 \% чеченцев.

Подавляющее большинство русских и русскоязычных, опрошенных в РА, КЧР, РД, РСО-А и ЧР, безусловно хотят жить в светском государстве. Практически каждый второй респондент - представитель коренного населения РА, РД и РСО-А хочет жить в светском государстве. Каждый третий респондент в КБР, КЧР выбрал вариант «безусловно в светском государстве».

Таблииа 3

Лично Вы хотели бы жить в светском или шариатском государстве? (в \%)

\begin{tabular}{|c|c|c|c|c|c|c|c|}
\hline \multirow[b]{2}{*}{ 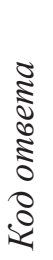 } & \multirow[b]{2}{*}{ Варианты ответа } & \multicolumn{2}{|c|}{ PA } & \multicolumn{2}{|c|}{ КБР } & \multicolumn{2}{|c|}{ КЧР } \\
\hline & & адыгейцы & $\begin{array}{c}\text { русские } \\
\text { и русско- } \\
\text { язычные }\end{array}$ & $\begin{array}{c}\text { кабар- } \\
\text { динцы, } \\
\text { балкарцы }\end{array}$ & $\begin{array}{l}\text { русские } \\
\text { и русско- } \\
\text { язычные }\end{array}$ & $\begin{array}{c}\text { карача- } \\
\text { евцы, } \\
\text { черкесы }\end{array}$ & $\begin{array}{c}\text { русские } \\
\text { и русско- } \\
\text { язычные }\end{array}$ \\
\hline 1 & $\begin{array}{l}\text { Безусловно в светском } \\
\text { государстве }\end{array}$ & 44,0 & 67,3 & 32,7 & 30,2 & 27,0 & 50,5 \\
\hline 2 & $\begin{array}{l}\text { Скорее в светском } \\
\text { государстве }\end{array}$ & 22,6 & 19,4 & 22,8 & 27,0 & 17,6 & 12,6 \\
\hline 3 & $\begin{array}{l}\text { Скорее в шариатском } \\
\text { государстве }\end{array}$ & 4,8 & 0,9 & 8,8 & 7,1 & 23,0 & 14,7 \\
\hline 4 & $\begin{array}{l}\text { Безусловно в шариатском } \\
\text { государстве }\end{array}$ & 1,2 & 0,5 & 1,8 & 3,2 & 10,8 & 4,2 \\
\hline 5 & $\begin{array}{l}\text { Затрудняюсь ответить, } \\
\text { отказ от ответа }\end{array}$ & 27,4 & 11,8 & 33,9 & 32,5 & 21,6 & 17,9 \\
\hline & & 100,0 & 100,0 & 100,0 & 100,0 & 100,0 & 100,0 \\
\hline
\end{tabular}




\section{Национальная безопасность $1(24) \cdot 2013$}

\begin{tabular}{|c|c|c|c|c|c|c|c|c|}
\hline \multirow[b]{2}{*}{ 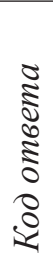 } & \multicolumn{2}{|c|}{ РД } & \multicolumn{2}{|c|}{ РИ } & \multicolumn{2}{|c|}{ PCO-A } & \multicolumn{2}{|c|}{ ЧР } \\
\hline & $\begin{array}{c}\text { народы } \\
\text { Дагестана }\end{array}$ & $\begin{array}{c}\text { русские } \\
\text { и русско- } \\
\text { язычные }\end{array}$ & ингуши & $\begin{array}{c}\text { русские } \\
\text { и русско- } \\
\text { язычные }\end{array}$ & осетины & $\begin{array}{c}\text { русские } \\
\text { и русско- } \\
\text { язычные }\end{array}$ & чеченцы & $\begin{array}{c}\text { русские } \\
\text { и русско- } \\
\text { язычные }\end{array}$ \\
\hline 1 & 49,4 & 75,9 & 8,9 & 22,2 & 49,3 & 62,1 & 19,5 & $\begin{array}{l}58,0 \\
\end{array}$ \\
\hline 2 & 14,5 & 11,5 & 17,0 & 5,6 & 22,3 & 14,9 & 28,9 & 21,0 \\
\hline 3 & 18,1 & 1,7 & 24,1 & 16,7 & 2,8 & 0,0 & 17,4 & 8,6 \\
\hline 4 & 2,4 & 0,6 & 23,2 & 27,8 & 0,9 & 2,3 & 8,9 & 2,5 \\
\hline 5 & 15,7 & 10,3 & 26,8 & 27,8 & 24,7 & 20,7 & 25,3 & 9,9 \\
\hline & 100,0 & 100,0 & 100,0 & 100,0 & 100,0 & 100,0 & 100,0 & 100,0 \\
\hline
\end{tabular}

В РИ и ЧР только малая часть коренного населения $(8,9 \%$ и $19,5 \%$ соответственно) хотела бы жить в светском государстве. В этих республиках желание респондентов жить в шариатском государстве можно объяснить тем, что национализм на Северном Кавказе опирается на ислам. Однако, как представляется, связь национализма и ислама имеет более опосредованный характер.

Идеология этнического национализма и ислам подпитывали друг друга в ситуациях самоопределения в отношении России как определенно неисламского государства. В условиях же обретенной самостоятельности возникает напряженность между исламом и национальной идеологией. Одним из проявлений этого противоречия является фрагментация единой организационной сети исламских учреждений, явная тенденция к их разделению по этническому признаку. Но именно кризис национальных протогосударств будет иметь всплеск исламизма как свое следствие. Кризис этнической (шариатской) государственности и этнических солидарностей обострил потребность в исламе как подлинном ресурсе солидарности и политической силы. Как нам кажется, с этой точки зрения можно объяснить установки респондентов в КЧР, РИ и ЧР.

Имеются незначительные различия в ответах респондентов по национальному и гендерному признакам (таблица 3.1). Первый вариант «безусловно в светском государстве» выбрали 79,2 \% русских и русскоязычных мужчин РД, 73,2 \% русских и русскоязычных женщин РД, 67,4 \% русских и русскоязыч- ных РА, 67,2 \% русских и русскоязычных женщин РА, $63,6 \%$ русских и русскоязычных ЧР, $62,7 \%$ русских и русскоязычных РСО-А, 61,1 \% русских и русскоязычных мужчин РСО-А, 53,2 \% осетин-мужчин, 53,1 \% народов Дагестана (мужчин), 51,5 \% русских и русскоязычных мужчин КЧР, $51,4 \%$ русских и русскоязычных мужчин ЧР, 46,3 \% осетинок, 45,7 \% адыгеек, 45,2 \% народов Дагестана, 42,1 \% адыгейцев-мужчин, 50 \% русских и русскоязычных женщин КЧР, 33,8 \% кабардинцев, балкарцев-мужчин, 33,3 \% женщин ингушской национальности, 29,4 \% карачаевцев, черкесов мужчин, $30,4 \%$ русских и русскоязычных мужчин КБР, 30,3 \% кабардинцев, балкарцев, 28,4 \% русских и русскоязычных женщин КБР, 25 \% карачаевцев и черкесов - женщин.

«Скорее в светском государстве» хотели бы жить $32,1 \%$ русских и русскоязычных мужчин КБР, 31 \% чеченок, $27 \%$ русских и русскоязычных мужчин ЧР, $26,7 \%$ чеченцев мужчин, 26,3 \% кабардинцев, балкарцев мужчин, 25 \% карачаевцев, черкесов женщин.

Затруднились с ответом каждый второй русский и русскоязычный респондент-мужчина в РИ, половина русских и русскоязычных респондентов-женщин в КБР; каждый третий кабардинец и балкарец (мужчины и женщины), треть ингушек; каждый четвертый чеченец - мужчины и женщины, четверть респондентов-адыгейцев мужчины и женщины, около 25 \% карачаевцев и черкесов - жителей КЧР; каждый пятый русский и русскоязычный респондент-мужчина в КБР, пятая часть опрошенных представительниц коренных национальностей в КЧР — карачаевок и 
черкешенок, представительниц народов Дагестана, каждый пятый мужчина - ингуш и осетин.

Как видим, большинство респондентов - жителей северокавказских республик независимо от гендерной принадлежности хотят жить в светском государстве. Как было сказано выше, исключение представляет коренное население РИ и ЧР - ингуши и чеченцы.

Таблииа 3.1

Лично Вых хотели бы жить в светском или шариатском государстве? (в \%)

\begin{tabular}{|c|c|c|c|c|c|c|c|c|c|}
\hline \multirow{3}{*}{ 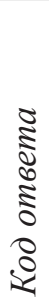 } & \multirow{3}{*}{ Варианты ответа } & \multicolumn{4}{|c|}{ PA } & \multicolumn{4}{|c|}{ КБР } \\
\hline & & \multicolumn{2}{|c|}{ адыгейцы } & \multicolumn{2}{|c|}{$\begin{array}{c}\text { русские и } \\
\text { русскоязычные }\end{array}$} & \multicolumn{2}{|c|}{$\begin{array}{c}\text { кабардинцы, } \\
\text { балкарцы }\end{array}$} & \multicolumn{2}{|c|}{$\begin{array}{c}\text { русские и } \\
\text { русскоязычные }\end{array}$} \\
\hline & & муж. & жен. & муж. & жен. & муж. & жен. & муж. & жен. \\
\hline 1 & $\begin{array}{l}\text { Безусловно в светском } \\
\text { государстве }\end{array}$ & 42,1 & 45,7 & 67,4 & 67,2 & 33,8 & 30,3 & 30,4 & 28,4 \\
\hline 2 & $\begin{array}{l}\text { Скорее в светском } \\
\text { государстве }\end{array}$ & 21,1 & 23,9 & 21,7 & 17,6 & 26,3 & 20,2 & 32,1 & 23,9 \\
\hline 3 & $\begin{array}{l}\text { Скорее в шариатском } \\
\text { государстве }\end{array}$ & 5,3 & 4,3 & 1,1 & 0,8 & 3,8 & 13,5 & 8,9 & 6,0 \\
\hline 4 & $\begin{array}{l}\text { Безусловно в шариатском } \\
\text { государстве }\end{array}$ & 2,6 & 0,0 & 0,0 & 0,8 & 2,5 & 1,1 & 7,1 & 0,0 \\
\hline 5 & $\begin{array}{l}\text { Затрудняюсь ответить, } \\
\text { отказ от ответа }\end{array}$ & 28,9 & 26,1 & 9,8 & 13,4 & 33,8 & 34,8 & 21,4 & 41,8 \\
\hline & & 100,0 & 100,0 & 100,0 & 100,0 & 100,0 & 100,0 & 100,0 & 100,0 \\
\hline
\end{tabular}

\begin{tabular}{|c|c|c|c|c|c|c|c|c|}
\hline \multirow{3}{*}{ 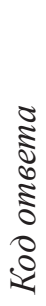 } & \multicolumn{4}{|c|}{ КЧР } & \multicolumn{4}{|c|}{ РД } \\
\hline & \multicolumn{2}{|c|}{ карачаевцы, черкесы } & \multicolumn{2}{|c|}{$\begin{array}{c}\text { русские и русско- } \\
\text { язычные }\end{array}$} & \multicolumn{2}{|c|}{ народы Дагестана } & \multicolumn{2}{|c|}{$\begin{array}{c}\text { русские и русско- } \\
\text { язычные }\end{array}$} \\
\hline & муж. & жен. & муж. & жен. & муж. & жен. & муж. & жен. \\
\hline 1 & 29,4 & 25,0 & 51,5 & 50,0 & 53,1 & 45,2 & 79,2 & 73,2 \\
\hline 2 & 8,8 & 25,0 & 12,1 & 12,9 & 16,0 & 13,1 & 9,1 & 13,4 \\
\hline 3 & 26,5 & 20,0 & 15,2 & 14,5 & 13,6 & 22,6 & 1,3 & 2,1 \\
\hline 4 & 11,8 & 10,0 & 0,0 & 6,5 & 4,9 & 0,0 & 0,0 & 1,0 \\
\hline
\end{tabular}




\section{Национальная безопасность 1(24) • 2013}

\begin{tabular}{|c|c|c|c|c|c|c|c|c|}
\hline \multirow{3}{*}{ 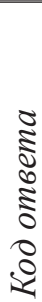 } & \multicolumn{4}{|c|}{ КЧР } & \multicolumn{4}{|c|}{ РД } \\
\hline & \multicolumn{2}{|c|}{ карачаевцы, черкесы } & \multicolumn{2}{|c|}{$\begin{array}{c}\text { русские и русско- } \\
\text { язычные }\end{array}$} & \multicolumn{2}{|c|}{ народы Дагестана } & \multicolumn{2}{|c|}{$\begin{array}{c}\text { русские и русско- } \\
\text { язычные }\end{array}$} \\
\hline & муж. & жен. & муж. & жен. & муж. & жен. & муж. & жен. \\
\hline 5 & 23,5 & 20,0 & 21,2 & 16,1 & 12,3 & 19,0 & 10,4 & 10,3 \\
\hline & 100,0 & 100,0 & 100,0 & 100,0 & 100,0 & 100,0 & 100,0 & 100,0 \\
\hline
\end{tabular}

\begin{tabular}{|c|c|c|c|c|c|c|c|c|c|c|c|c|}
\hline \multirow{3}{*}{ 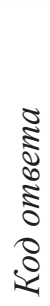 } & \multicolumn{4}{|c|}{ РИ } & \multicolumn{4}{|c|}{ PCO-A } & \multicolumn{4}{|c|}{ ЧР } \\
\hline & \multicolumn{2}{|c|}{ ингуши } & \multicolumn{2}{|c|}{$\begin{array}{c}\text { русские и } \\
\text { русскоязычные }\end{array}$} & \multicolumn{2}{|c|}{ осетины } & \multicolumn{2}{|c|}{$\begin{array}{c}\text { русские и } \\
\text { русскоязычные }\end{array}$} & \multicolumn{2}{|c|}{ чеченцы } & \multicolumn{2}{|c|}{$\begin{array}{c}\text { русские и } \\
\text { русскоязычные }\end{array}$} \\
\hline & муж. & жен. & муж. & жен. & муж. & жен. & муж. & жен. & муж. & жен. & муж. & жен. \\
\hline 1 & 8,6 & 9,3 & 11,1 & 33,3 & 53,2 & 46,3 & 61,1 & 62,7 & 14,4 & 24,0 & 51,4 & 63,6 \\
\hline 2 & 12,1 & 22,2 & 0,0 & 11,1 & 21,3 & 23,1 & 8,3 & 19,6 & 26,7 & 31,0 & 27,0 & 15,9 \\
\hline 3 & 31,0 & 16,7 & 11,1 & 22,2 & 2,1 & 3,3 & 0,0 & 0,0 & 24,4 & 11,0 & 5,4 & 11,4 \\
\hline 4 & 27,6 & 18,5 & 33,3 & 22,2 & 1,1 & 8 & 2,8 & 2,0 & 8,9 & 9,0 & 0,0 & 4,5 \\
\hline 5 & 20,7 & 33,3 & 44,4 & 11,1 & 22,3 & 26,4 & 27,8 & 15,7 & 25,6 & 25,0 & 16,2 & 4,5 \\
\hline & 100,0 & 100,0 & 100,0 & 100,0 & 100,0 & 100,0 & 100,0 & 100,0 & 100,0 & 100,0 & 100,0 & 100,0 \\
\hline
\end{tabular}

Что касается распределения ответов в зависимости от возраста опрошенных, результаты таковы: респонденты старшего поколения - из возрастной когорты старше 35 лет - в РИ (5 \%) и в ЧР (23\%), безусловно, хотят жить в светском государстве, среди представителей коренного населения этих республик моложе 35 лет в РИ этот вариант выбрали 13,5 \% респондентов, в ЧР - 13,2 \% (таблица 3.2).

В светском государстве хотели бы жить: 78,3 \% русских и русскоязычных респондентов старше 35 лет, живущих в РД, 72,4\% русских и русскоязычных до 35 лет в ЧР, 72,3\% русских и русскоязычных старше 35 лет в РА, $64,9 \%$ русских и русскоязычных старше 35 лет в РСО-А, 59,2 \% респондентов - представителей коренных народов Дагестана старше 35 лет, 56,7 \% русских и русскоязычных в РСО-А до 35 лет, 53,6 \% адыгейцев до 35 лет, $52 \%$ осетин до 35 лет, 51,5\% русских и русскоязычных старше 35 лет в КЧР, 50 \% русских и русскоязычных старше 35 лет в ЧР, 48,9\% русских и русскоязычных до 35 лет в РА, 48,3\% русских и русскоязычных до 35 лет в КЧР, 46,9 \% осетин старше 35 лет, 42,9 \% карачаевцев и черкесов старше 35 лет, 39,3\% адыгейцев старше 35 лет, $38,7 \%$ русских и русскоязычных респондентов моложе 35 лет, живущих в КБР, 37,6 \% кабардинцев и балкарцев старше 35 лет, 35,3\% представителей коренных народов Дагестана моложе 35 лет, 28,6 \% русских и русскоязычных до 35 лет в РИ, 25,7 \% кабардинцев и балкарцев до 35 лет.

Вариант «безусловно в шариатском государстве» выбрали: в РИ - 28,6 \% русских и русскоязычных моложе 35 лет и 27,3 \% старше 35 лет, 25 \% ингушей моложе 35 лет. 
Не ответили по разным причинам на вопрос: кабардинцы и балкарцы до 35 лет (35,7 \%), ингуши старше 35 лет (33,3 \%), кабардинцы и балкарцы старше 35 лет (32,7 \%), адыгейцы до 35 лет (32,1 \%), рус- ские и русскоязычные в КБР старше 35 лет $(33,7 \%)$, в РИ - русские и русскоязычные до 35 лет - $28,6 \%$ и старше 35 лет - 27,3\%, русские и русскоязычные КБР до 35 лет (29 \%), адыгейцы старше 35 лет (25\%).

Таблица 3.2 Лично Вых хотели бы жить в светском или шариатском государстве? (в \%)

\begin{tabular}{|c|c|c|c|c|c|c|c|c|c|}
\hline \multirow{3}{*}{ 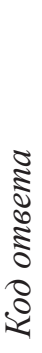 } & \multirow{3}{*}{ Варианты ответа } & \multicolumn{4}{|c|}{ PA } & \multicolumn{4}{|c|}{ КБР } \\
\hline & & \multicolumn{2}{|c|}{ адыгейцы } & \multicolumn{2}{|c|}{$\begin{array}{c}\text { русские и } \\
\text { русскоязычные }\end{array}$} & \multicolumn{2}{|c|}{$\begin{array}{c}\text { кабардинцы, } \\
\text { балкарцы }\end{array}$} & \multicolumn{2}{|c|}{$\begin{array}{c}\text { русские и } \\
\text { русскоязычные }\end{array}$} \\
\hline & & $\begin{array}{c}\text { до } \\
35 \text { лет }\end{array}$ & $\begin{array}{l}\text { старше } \\
35 \text { лет }\end{array}$ & $\begin{array}{c}\text { до } \\
35 \text { лет }\end{array}$ & $\begin{array}{l}\text { старше } \\
35 \text { лет }\end{array}$ & $\begin{array}{c}\text { до } \\
35 \text { лет }\end{array}$ & $\begin{array}{l}\text { старше } \\
35 \text { лет }\end{array}$ & $\begin{array}{c}\text { до } \\
35 \text { лет }\end{array}$ & $\begin{array}{l}\text { старше } \\
35 \text { лет }\end{array}$ \\
\hline 1 & $\begin{array}{l}\text { Безусловно в светском } \\
\text { государстве }\end{array}$ & 53,6 & 39,3 & 48,9 & 72,3 & 25,7 & 37,6 & 38,7 & 27,4 \\
\hline 2 & $\begin{array}{l}\text { Скорее в светском } \\
\text { государстве }\end{array}$ & 14,3 & 26,8 & 28,9 & 16,9 & 28,6 & 18,8 & 25,8 & 27,4 \\
\hline 3 & $\begin{array}{l}\text { Скорее в шариатском } \\
\text { государстве }\end{array}$ & 0,0 & 7,1 & 4,4 & 0,0 & 8,6 & 8,9 & 3,2 & 8,4 \\
\hline 4 & $\begin{array}{l}\text { Безусловно в шариатском } \\
\text { государстве }\end{array}$ & 0,0 & 1,8 & 0,0 & 0,6 & 1,4 & 2,0 & 3,2 & 3,2 \\
\hline 5 & $\begin{array}{l}\text { Затрудняюсь ответить, } \\
\text { отказ от ответа }\end{array}$ & 32,1 & 25,0 & 17,8 & 10,2 & 35,7 & 32,7 & 29,0 & 33,7 \\
\hline & & 100,0 & 100,0 & 100,0 & 100,0 & 100,0 & 100,0 & 100,0 & 100,0 \\
\hline
\end{tabular}

\begin{tabular}{|c|c|c|c|c|c|c|c|c|}
\hline \multirow{3}{*}{ 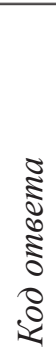 } & \multicolumn{4}{|c|}{ КЧР } & \multicolumn{4}{|c|}{ РД } \\
\hline & \multicolumn{2}{|c|}{ карачаевцы, черкесы } & \multicolumn{2}{|c|}{$\begin{array}{c}\text { русские и русско- } \\
\text { язычные }\end{array}$} & \multicolumn{2}{|c|}{ народы Дагестана } & \multicolumn{2}{|c|}{$\begin{array}{c}\text { русские и русско- } \\
\text { язычные }\end{array}$} \\
\hline & до 35 лет & $\begin{array}{c}\text { старше } \\
35 \text { лет }\end{array}$ & до 35 лет & $\begin{array}{l}\text { старше } \\
35 \text { лет }\end{array}$ & до 35 лет & $\begin{array}{l}\text { старше } \\
35 \text { лет }\end{array}$ & до 35 лет & $\begin{array}{l}\text { старше } \\
35 \text { лет }\end{array}$ \\
\hline 1 & 20,8 & 42,9 & 48,3 & 51,5 & 35,3 & 59,2 & 59,1 & 78,3 \\
\hline 2 & 20,8 & 9,5 & 17,2 & 10,6 & 13,2 & 15,3 & 22,7 & 9,9 \\
\hline 3 & 20,8 & 28,6 & 17,2 & 13,6 & 30,9 & 9,2 & 4,5 & 1,3 \\
\hline
\end{tabular}




\section{Национальная безопасность 1(24) • 2013}

\begin{tabular}{|c|c|c|c|c|c|c|c|c|}
\hline \multirow{3}{*}{ 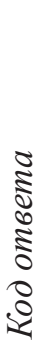 } & \multicolumn{4}{|c|}{ КЧР } & \multicolumn{4}{|c|}{ РД } \\
\hline & \multicolumn{2}{|c|}{ карачаевцы, черкесы } & \multicolumn{2}{|c|}{$\begin{array}{c}\text { русские и русско- } \\
\text { язычные }\end{array}$} & \multicolumn{2}{|c|}{ народы Дагестана } & \multicolumn{2}{|c|}{$\begin{array}{c}\text { русские и русско- } \\
\text { язычные }\end{array}$} \\
\hline & до 35 лет & $\begin{array}{l}\text { старше } \\
35 \text { лет }\end{array}$ & до 35 лет & $\begin{array}{l}\text { старше } \\
35 \text { лет }\end{array}$ & до 35 лет & $\begin{array}{l}\text { старше } \\
35 \text { лет }\end{array}$ & до 35 лет & $\begin{array}{l}\text { старше } \\
35 \text { лет }\end{array}$ \\
\hline 4 & 13,2 & 4,8 & 6,9 & 3,0 & 4,4 & 1,0 & 0,0 & 0,7 \\
\hline 5 & 24,5 & 14,3 & 10,3 & 21,2 & 16,2 & 15,3 & 13,6 & 9,9 \\
\hline & 100,0 & 100,0 & 100,0 & 100,0 & 100,0 & 100,0 & 100,0 & 100,0 \\
\hline
\end{tabular}

\begin{tabular}{|c|c|c|c|c|c|c|c|c|c|c|c|c|}
\hline \multirow{3}{*}{ 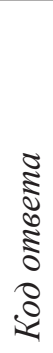 } & \multicolumn{4}{|c|}{ РИ } & \multicolumn{4}{|c|}{ PCO-A } & \multicolumn{4}{|c|}{ ЧР } \\
\hline & \multicolumn{2}{|c|}{ ингуши } & \multicolumn{2}{|c|}{$\begin{array}{c}\text { русские и } \\
\text { русскоязычные }\end{array}$} & \multicolumn{2}{|c|}{ осетины } & \multicolumn{2}{|c|}{$\begin{array}{c}\text { русские и } \\
\text { русскоязычные }\end{array}$} & \multicolumn{2}{|c|}{ чеченцы } & \multicolumn{2}{|c|}{$\begin{array}{c}\text { русские и } \\
\text { русскоязычные }\end{array}$} \\
\hline & $\begin{array}{c}\text { до } \\
35 \text { лет }\end{array}$ & $\begin{array}{c}\text { старше } \\
35 \text { лет }\end{array}$ & $\begin{array}{c}\text { до } \\
35 \text { лет }\end{array}$ & $\begin{array}{l}\text { старше } \\
35 \text { лет }\end{array}$ & $\begin{array}{c}\text { до } \\
35 \text { лет }\end{array}$ & \begin{tabular}{|l|} 
старше \\
35 лет
\end{tabular} & $\begin{array}{c}\text { до } \\
35 \text { лет }\end{array}$ & $\begin{array}{l}\text { старше } \\
35 \text { лет }\end{array}$ & $\begin{array}{c}\text { до } \\
35 \text { лет }\end{array}$ & $\begin{array}{l}\text { старше } \\
35 \text { лет }\end{array}$ & $\begin{array}{c}\text { до } \\
35 \text { лет }\end{array}$ & \begin{tabular}{|c|} 
старше \\
35 лет
\end{tabular} \\
\hline 1 & 13,5 & 5,0 & 28,6 & 18,2 & 52,0 & 46,9 & 56,7 & 64,9 & 13,2 & 23,0 & 72,4 & 50,0 \\
\hline 2 & 19,2 & 15,0 & 0,0 & 9,1 & 22,5 & 22,1 & 13,3 & 15,8 & 26,5 & 30,3 & 13,8 & 25,0 \\
\hline 3 & 23,1 & 25,0 & 14,3 & 18,2 & 0,0 & 5,3 & 0,0 & 0,0 & 14,7 & 18,9 & 3,4 & 11,5 \\
\hline 4 & 25,0 & 21,7 & 28,6 & 27,3 & 1,0 & 0,9 & 3,3 & 1,8 & 10,3 & 8,2 & 0,0 & 3,8 \\
\hline 5 & 19,2 & 33,3 & 28,6 & 27,3 & 24,5 & 24,8 & 26,7 & 17,5 & 35,3 & 19,7 & 10,3 & 9,6 \\
\hline & 100,0 & 100,0 & 100,0 & 100,0 & 100,0 & 100,0 & 100,0 & 100,0 & 100,0 & 100,0 & 100,0 & 100,0 \\
\hline
\end{tabular}

Значимым фактором при выборе ответа оказалось образование (таблица 3.3). Затруднились с ответом или отказались отвечать на этот вопрос: 72,7 \% русских и русскоязычных респондентов - жителей ЧР с неоконченным высшим и высшим образованием, 69,8 \% русских и русскоязычных респондентов с неоконченным высшим и высшим образованием и $68,2 \%$ - со средним специальным и ниже образованием, живущих в РА, 62,7 \% представителей коренных народов РД с неоконченным высшим, высшим образованием, 81 \% русских и русскоязычных жителей РД со средним специальным и ниже образованием, 68,5 \% русских и русскоязычных с неоконченным высшим, высшим образованием в РСО-А, 64,9 \% русских и русскоязычных с неоконченным высшим и высшим образованием - жителей РД, 62,1 \% адыгейцев с неоконченным высшим и высшим образованием, 58,8 \% кабардинцев и балкарцев со средним специальным и ниже образованием, 52,1\% осетин с неоконченным высшим и высшим образованием, 51,7 \% русских и русскоязычных жителей ЧР со средним специальным (ПТУ, техникум) и ниже образованием, $51,5 \%$ русских и русскоязычных респондентов в РСО-А со средним специальным образованием и ниже, $50,8 \%$ русских и русскоязычных со средним специальным и ниже образованием в КЧР, $50 \%$ русских и русскоязычных респондентов с неокон- 
Внутренние угрозы и контрмеры

ченным высшим и высшим образованием в КЧР, 46,7 \% осетин со средним специальным и ниже образованием, 42 \% кабардинцев и балкарцев с неоконченным высшим и высшим образованием, 40,2 \% представителей коренных народов РД со средним специальным образованием и ниже, 37,5 \% русских и русскоязычных респондентов - жителей РИ со средним специальным и ниже образованием, 35,8 \% русских и русскоязычных респондентов с неоконченным высшим и высшим образованием в КБР, 35,2 \% адыгейцев со средним специальным и ниже образованием, 27,3 \% карачаевцев и черкесов с неоконченным высшим и высшим образованием, 26,3 \% карачаевцев и черкесов со средним специальным и ниже образованием.
Вариант «безусловно в шариатском государстве» выбрали русские и русскоязычные респонденты жители РИ с неоконченным высшим, высшим образованием $(33,3 \%)$.

Примечательно, что практически абсолютное большинство русских и русскоязычных респондентов, имеющих среднее специальное и ниже образование - в РД и неоконченное высшее и высшее - в ЧР, безусловно хотят жить в светском государстве. Меньше всего желающих жить в светском государстве среди респондентов коренной национальности - жителей РИ независимо от образования и ЧР - среди респондентов, имеющих среднее специальное и ниже образование.

Таблица 3.3

Лично Вы хотели бы жить в светском или шариатском государстве? (в \%)

\begin{tabular}{|c|c|c|c|c|c|c|c|c|c|}
\hline \multirow{3}{*}{ 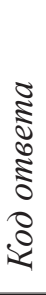 } & \multirow{3}{*}{ Варианты ответа } & \multicolumn{4}{|c|}{$\mathrm{PA}$} & \multicolumn{4}{|c|}{ КБР } \\
\hline & & \multicolumn{2}{|c|}{ адыгейцы } & \multicolumn{2}{|c|}{$\begin{array}{c}\text { русские и рус- } \\
\text { скоязычные }\end{array}$} & \multicolumn{2}{|c|}{$\begin{array}{c}\text { кабардинцы, } \\
\text { балкарцы }\end{array}$} & \multicolumn{2}{|c|}{$\begin{array}{l}\text { русские и рус- } \\
\text { скоязычные }\end{array}$} \\
\hline & & $\begin{array}{c}\text { cp. } \\
\text { спец. и } \\
\text { ниже }\end{array}$ & $\begin{array}{l}\text { н/в, } \\
\text { выс- } \\
\text { шее }\end{array}$ & $\begin{array}{c}\text { ср. } \\
\text { спец. и } \\
\text { ниже }\end{array}$ & $\begin{array}{l}\text { н/в, } \\
\text { выс- } \\
\text { шее }\end{array}$ & $\begin{array}{c}\text { ср. } \\
\text { спец. и } \\
\text { ниже }\end{array}$ & $\begin{array}{l}\text { н/в, } \\
\text { выс- } \\
\text { шее }\end{array}$ & $\begin{array}{c}\text { ср. } \\
\text { спец. и } \\
\text { ниже }\end{array}$ & $\begin{array}{l}\text { н/в, } \\
\text { выс- } \\
\text { шее }\end{array}$ \\
\hline 1 & $\begin{array}{l}\text { Безусловно в светском го- } \\
\text { сударстве }\end{array}$ & 35,2 & 62,1 & 68,2 & 69,8 & 58,8 & 42,0 & 18,4 & 35,8 \\
\hline 2 & $\begin{array}{l}\text { Скорее в светском государ- } \\
\text { стве }\end{array}$ & 27,8 & 10,3 & 18,8 & 20,8 & 11,8 & 32,0 & 32,7 & 20,8 \\
\hline 3 & $\begin{array}{l}\text { Скорее в шариатском госу- } \\
\text { дарстве }\end{array}$ & 5,6 & 3,4 & 1,3 & 0,0 & 0,0 & 4,0 & 8,2 & 5,7 \\
\hline 4 & $\begin{array}{l}\text { Безусловно в шариатском } \\
\text { государстве }\end{array}$ & 1,9 & 0,0 & 0,6 & 0,0 & 2,9 & 0,0 & 4,1 & 3,8 \\
\hline 5 & $\begin{array}{l}\text { Затрудняюсь ответить, от- } \\
\text { каз от ответа }\end{array}$ & 29,6 & 24,1 & 11,0 & 9,4 & 26,5 & 22,0 & 36,7 & 34,0 \\
\hline & & 100,0 & 100,0 & 100,0 & 100,0 & 100,0 & 100,0 & 100,0 & 100,0 \\
\hline
\end{tabular}

\begin{tabular}{|c|c|c|c|c|c|c|c|c|}
\hline \multirow{3}{*}{ 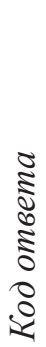 } & \multicolumn{4}{|c|}{ КЧР } & \multicolumn{4}{|c|}{ РД } \\
\hline & \multicolumn{2}{|c|}{ карачаевцы, черкесы } & \multicolumn{2}{|c|}{$\begin{array}{c}\text { русские и русско- } \\
\text { язычные }\end{array}$} & \multicolumn{2}{|c|}{ народы Дагестана } & \multicolumn{2}{|c|}{$\begin{array}{c}\text { русские и русско- } \\
\text { язычные }\end{array}$} \\
\hline & $\begin{array}{c}\text { ср. спец. и } \\
\text { ниже }\end{array}$ & н/в, высшее & $\begin{array}{c}\text { ср. спец. и } \\
\text { ниже }\end{array}$ & н/в, высшее & $\begin{array}{c}\text { ср. спец. и } \\
\text { ниже }\end{array}$ & н/в, высшее & $\begin{array}{c}\text { ср. спец. и } \\
\text { ниже }\end{array}$ & н/в, высшее \\
\hline 1 & 26,3 & 27,3 & 50,8 & 50,0 & 40,2 & 62,7 & 81,0 & 64,9 \\
\hline
\end{tabular}




\section{Национальная безопасность 1(24) • 2013}

\begin{tabular}{|c|c|c|c|c|c|c|c|c|}
\hline \multirow{3}{*}{ 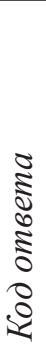 } & \multicolumn{4}{|c|}{ КЧР } & \multicolumn{4}{|c|}{ РД } \\
\hline & \multicolumn{2}{|c|}{ карачаевцы, черкесы } & \multicolumn{2}{|c|}{$\begin{array}{c}\text { русские и русско- } \\
\text { язычные }\end{array}$} & \multicolumn{2}{|c|}{ народы Дагестана } & \multicolumn{2}{|c|}{$\begin{array}{c}\text { русские и русско- } \\
\text { язычные }\end{array}$} \\
\hline & $\begin{array}{l}\text { ср. спец. и } \\
\text { ниже }\end{array}$ & н/в, высшее & $\begin{array}{l}\text { ср. спец. и } \\
\text { ниже }\end{array}$ & н/в, высшее & $\begin{array}{l}\text { ср. спец. и } \\
\text { ниже }\end{array}$ & н/в, высшее & $\begin{array}{c}\text { ср. спец. и } \\
\text { ниже }\end{array}$ & н/в, высшее \\
\hline 2 & 15,8 & 18,2 & 13,6 & 11,8 & 14,4 & 14,9 & 9,5 & 15,8 \\
\hline 3 & 36,8 & 18,2 & 15,3 & 14,7 & 21,6 & 13,4 & 0,9 & 3,5 \\
\hline 4 & 0,0 & 14,5 & 3,4 & 5,9 & 4,1 & 0,0 & 0,0 & 1,8 \\
\hline 5 & 21,1 & 21,8 & 16,9 & 17,6 & 19,6 & 9,0 & 8,6 & 14,0 \\
\hline & 100,0 & 100,0 & 100,0 & 100,0 & 100,0 & 100,0 & 100,0 & 100,0 \\
\hline
\end{tabular}

\begin{tabular}{|c|c|c|c|c|c|c|c|c|c|c|c|c|}
\hline \multirow[b]{3}{*}{ 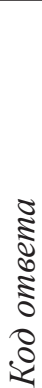 } & \multicolumn{4}{|c|}{ РИ } & \multicolumn{4}{|c|}{ PCO-A } & \multicolumn{4}{|c|}{ ЧР } \\
\hline & \multicolumn{2}{|c|}{ ингуши } & \multicolumn{2}{|c|}{$\begin{array}{c}\text { русские и рус- } \\
\text { скоязычные }\end{array}$} & \multicolumn{2}{|c|}{ осетины } & \multicolumn{2}{|c|}{$\begin{array}{c}\text { русские и рус- } \\
\text { скоязычные }\end{array}$} & \multicolumn{2}{|c|}{ чеченцы } & \multicolumn{2}{|c|}{$\begin{array}{c}\text { русские и рус- } \\
\text { скоязычные }\end{array}$} \\
\hline & $\begin{array}{c}\text { ср. } \\
\text { спец. и } \\
\text { ниже }\end{array}$ & $\begin{array}{l}\text { н/в, } \\
\text { выс- } \\
\text { шеe }\end{array}$ & $\begin{array}{c}\text { сp. } \\
\text { спец. и } \\
\text { ниже }\end{array}$ & $\begin{array}{l}\text { н/в, } \\
\text { выс- } \\
\text { шеe }\end{array}$ & $\begin{array}{c}\text { ср. } \\
\text { спец. и } \\
\text { ниже }\end{array}$ & $\begin{array}{c}\text { н/в, } \\
\text { выс- } \\
\text { шеe }\end{array}$ & $\begin{array}{c}\text { ср. } \\
\text { спец. и } \\
\text { ниже }\end{array}$ & $\begin{array}{c}\text { н/в, } \\
\text { выс- } \\
\text { шеe }\end{array}$ & $\begin{array}{c}\text { cp. } \\
\text { спец. и } \\
\text { ниже }\end{array}$ & $\begin{array}{c}\text { н/в, } \\
\text { выс- } \\
\text { шее }\end{array}$ & $\begin{array}{c}\text { ср. } \\
\text { спец. и } \\
\text { ниже }\end{array}$ & $\begin{array}{c}\text { н/в, } \\
\text { выс- } \\
\text { шее }\end{array}$ \\
\hline 1 & 9,7 & 9,1 & 37,5 & 11,1 & 46,7 & 52,1 & 51,5 & 68,5 & 16,7 & 24,2 & 51,7 & 72,7 \\
\hline 2 & 9,7 & 29,5 & 12,5 & 0,0 & 21,1 & 21,5 & 15,2 & 14,8 & 31,0 & 25,8 & 25,9 & 9,1 \\
\hline 3 & 21,0 & 29,5 & 25,0 & 11,1 & 3,3 & 2,5 & 0,0 & 0,0 & 14,3 & 24,2 & 8,6 & 9,1 \\
\hline 4 & 21,0 & 20,5 & 12,5 & 33,3 & 0,0 & 1,7 & 3,0 & 1,9 & 9,5 & 6,5 & 1,7 & 4,5 \\
\hline 5 & 38,7 & 11,4 & 12,5 & 44,4 & 28,9 & 22,3 & 30,3 & 14,8 & 28,6 & 19,4 & 12,1 & 4,5 \\
\hline & 100,0 & 100,0 & 100,0 & 100,0 & 100,0 & 100,0 & 100,0 & 100,0 & 100,0 & 100,0 & 100,0 & 100,0 \\
\hline
\end{tabular}

В зависимости от типа местности проживания респондентов (таблица 3. 4) ответы распределились следующим образом: в светском государстве безусловно хотели бы жить 79 \% русских и русскоязычных сельчан и 73,1 \% горожан в РД, 72,7 \% адыгейцев горожан, 70,8 \% русских и русскоязычных сельчан в ЧР, 72,3 \% русских и русскоязычных горожан в РА, $67,6 \%$ русских и русскоязычных сельчан в КЧР,
66,3 \% респондентов - представителей коренных народов Дагестана - горожан, 64,3 \% русских и русскоязычных горожан в РСО-А, $61,6 \%$ русских и русскоязычных сельчан в РА, $52,9 \%$ русских и русскоязычных сельчан в РСО-А, $53 \%$ осетин горожан, $44,9 \%$ осетин сельчан, $39,7 \%$ русских и русскоязычных горожан в КЧР, 37,5 \% сельчан — карачаевцев и черкесов, 35,7 \% русских и русскоязычных сельчан в 
Внутренние угрозы и контрмеры

КБР, 35 \% сельчан - кабардинцев и балкарцев, 33,3 \% русских и русскоязычных горожан в РИ, 33,7 \% коренных народов Дагестана - сельчан, 28,9 \% русских и русскоязычных горожан в КБР, 28,6 \% кабардинцев и балкарцев - горожан, 25,5 \% адыгейцев сельчан. Там, где нет легитимного большинства, в случае объединения данных первого и второго вариантов получаются следующие данные: 40,4 \% карачаевцев и черкесов горожан в КЧР, 40 \% ингушей горожан, $46 \%$ чеченцев горожан в ЧР, 55 \% чеченцев сельчан,
$37,6 \%$ русских и русскоязычных горожан в ЧР предпочитают жить в светском государстве. Меньше всего желающих жить в светском государстве среди ингушей - сельских жителей (17,1\%).

Безусловно, хотели бы жить в шариатском государстве $26,8 \%$ ингушей сельчан и $25 \%$ русских и русскоязычных горожан - жителей РИ. Больше всего затруднившихся с ответом среди адыгейцев-сельчан (39,2 \%), кабардинцев и балкарцев сельчан (35\%), русских и русскоязычных сельчан в КБР $(35,7 \%)$.

Таблича 3.4

Лично Вы хотели бы жить в светском или шариатском государстве? (в \%)

\begin{tabular}{|c|c|c|c|c|c|c|c|c|c|}
\hline \multirow{3}{*}{ 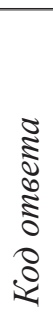 } & \multirow{3}{*}{ Варианты ответа } & \multicolumn{4}{|c|}{ PA } & \multicolumn{4}{|c|}{ КБР } \\
\hline & & \multicolumn{2}{|c|}{ адыгейцы } & \multicolumn{2}{|c|}{$\begin{array}{c}\text { русские и } \\
\text { русскоязычные }\end{array}$} & \multicolumn{2}{|c|}{$\begin{array}{l}\text { кабардинцы, } \\
\text { балкарцы }\end{array}$} & \multicolumn{2}{|c|}{$\begin{array}{c}\text { русские и } \\
\text { русскоязычные }\end{array}$} \\
\hline & & город & село & город & село & город & село & город & село \\
\hline 1 & $\begin{array}{l}\text { Безусловно в светском } \\
\text { государстве }\end{array}$ & 72,7 & 25,5 & 72,3 & 61,6 & 28,6 & 35,0 & 28,9 & 35,7 \\
\hline 2 & $\begin{array}{l}\text { Скорее в светском } \\
\text { государстве }\end{array}$ & 18,2 & 25,5 & 16,1 & 23,2 & 25,7 & 21,0 & 29,9 & 17,9 \\
\hline 3 & $\begin{array}{l}\text { Скорее в шариатском } \\
\text { государстве }\end{array}$ & 0,0 & 7,8 & 0,9 & 1,0 & 11,4 & 7,0 & 6,2 & 10,7 \\
\hline 4 & $\begin{array}{l}\text { Безусловно в шариатском } \\
\text { государстве }\end{array}$ & 0,0 & 2,0 & 0,0 & 1,0 & 1,4 & 2,0 & 4,1 & 0,0 \\
\hline 5 & $\begin{array}{l}\text { Затрудняюсь ответить, } \\
\text { отказ от ответа }\end{array}$ & 9,1 & 39,2 & 10,7 & 13,1 & 32,9 & 35,0 & 30,9 & 35,7 \\
\hline & & 100,0 & 100,0 & 100,0 & 100,0 & 100,0 & 100,0 & 100,0 & 100,0 \\
\hline
\end{tabular}

\begin{tabular}{|c|c|c|c|c|c|c|c|c|}
\hline \multirow{3}{*}{ 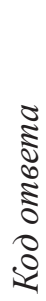 } & \multicolumn{4}{|c|}{ КЧР } & \multicolumn{4}{|c|}{ РД } \\
\hline & \multicolumn{2}{|c|}{ карачаевцы, черкесы } & \multicolumn{2}{|c|}{$\begin{array}{c}\text { русские и русско- } \\
\text { язычные }\end{array}$} & \multicolumn{2}{|c|}{ народы Дагестана } & \multicolumn{2}{|c|}{$\begin{array}{c}\text { русские и русско- } \\
\text { язычные }\end{array}$} \\
\hline & город & село & город & село & город & село & город & село \\
\hline 1 & 19,0 & 37,5 & 39,7 & 67,6 & 66,3 & 33,7 & 73,1 & 79,0 \\
\hline 2 & 21,4 & 12,5 & 13,8 & 10,8 & 15,0 & 14,0 & 8,6 & 14,8 \\
\hline
\end{tabular}




\section{Национальная безопасность $1(24) \cdot 2013$}

\begin{tabular}{|c|c|c|c|c|c|c|c|c|}
\hline \multirow{3}{*}{ 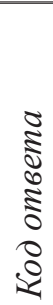 } & \multicolumn{4}{|c|}{ КЧР } & \multicolumn{4}{|c|}{ РД } \\
\hline & \multicolumn{2}{|c|}{ карачаевцы, черкесы } & \multicolumn{2}{|c|}{$\begin{array}{c}\text { русские и русско- } \\
\text { язычные }\end{array}$} & \multicolumn{2}{|c|}{ народы Дагестана } & \multicolumn{2}{|c|}{$\begin{array}{c}\text { русские и русско- } \\
\text { язычные }\end{array}$} \\
\hline & город & село & город & село & город & село & город & село \\
\hline 3 & 16,7 & 31,3 & 20,7 & 5,4 & 8,8 & 26,7 & 2,2 & 1,2 \\
\hline 4 & 14,3 & 6,3 & 3,4 & 5,4 & 1,3 & 3,5 & 1,1 & 0,0 \\
\hline 5 & 28,6 & 12,5 & 22,4 & 10,8 & 8,8 & 22,1 & 15,1 & 4,9 \\
\hline & 100,0 & 100,0 & 100,0 & 100,0 & 100,0 & 100,0 & 100,0 & 100,0 \\
\hline
\end{tabular}

\begin{tabular}{|c|c|c|c|c|c|c|c|c|c|c|c|c|}
\hline \multirow{3}{*}{ 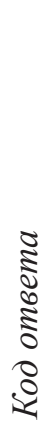 } & \multicolumn{4}{|c|}{ РИ } & \multicolumn{4}{|c|}{ PCO-A } & \multicolumn{4}{|c|}{ ЧР } \\
\hline & \multicolumn{2}{|c|}{ ингуши } & \multicolumn{2}{|c|}{$\begin{array}{c}\text { русские и рус- } \\
\text { скоязычные }\end{array}$} & \multicolumn{2}{|c|}{ осетины } & \multicolumn{2}{|c|}{$\begin{array}{c}\text { русские и рус- } \\
\text { скоязычные }\end{array}$} & \multicolumn{2}{|c|}{ чеченцы } & \multicolumn{2}{|c|}{$\begin{array}{c}\text { русские и рус- } \\
\text { скоязычные }\end{array}$} \\
\hline & город & село & город & село & город & село & город & село & город & село & город & село \\
\hline 1 & 11,3 & 4,9 & 33,3 & 0,0 & 53,0 & 44,9 & 64,3 & 52,9 & 18,4 & 20,4 & 6,3 & 70,8 \\
\hline 2 & 19,7 & 12,2 & 8,3 & 0,0 & 23,1 & 21,4 & 12,9 & 23,5 & 27,6 & 30,1 & 31,3 & 18,5 \\
\hline 3 & 26,8 & 19,5 & 8,3 & 33,3 & 5,1 & 0,0 & 0,0 & 0,0 & 18,4 & 16,5 & 25,0 & 4,6 \\
\hline 4 & 21,1 & 26,8 & 25,0 & 33,3 & 1,7 & 0,0 & 1,4 & 5,9 & 9,2 & 8,7 & 12,5 & 0,0 \\
\hline 5 & 21,1 & 36,6 & 25,0 & 33,3 & 17,1 & 33,7 & 21,4 & 17,6 & 26,4 & 24,3 & 25,0 & 6,2 \\
\hline & 100,0 & 100,0 & 100,0 & 100,0 & 100,0 & 100,0 & 100,0 & 100,0 & 100,0 & 100,0 & 100,0 & 100,0 \\
\hline
\end{tabular}

Как видим, большинство русских и русскоязычных респондентов - как горожан, так и сельчан, живущих в РА, РД, КЧР, РСО-А и ЧР, хотят жить в светском государстве, равно как и представители коренного населения - горожан в РА, РД и РСО-А.

Число респондентов, желающих жить в шариатском государстве, невелико: $2,7 \%$ - в РА; $10,5 \%$ - в КБР; 25,4 \% - в КЧР; $12,8 \%$ - в РД; $50,7 \%$ - в РИ; 3,3\%— в РСО-А; 21,8 \%- в ЧР. Только в двух республиках таких более половины опрошенных — в РИ и КЧР.
По мнению многих наших экспертов, каждый хотел бы жить там, где родился, с законами, которые вошли в их кровь и плоть. Этот фактор надо учитывать при анализе политической ситуации в регионе. Например, чеченцев депортировали в сороковых годах прошлого века. Затем, когда они стали возвращаться, с ними вернулись внуки, которые не пережили депортацию. Но это абсолютно не помешало тому, чтобы они объединились и начали воевать с Россией. Когда речь идет о религиозных и национальных вопросах, по всей видимости, надо 


\section{Внутренние угрозы и контрмеры}

рассматривать и самосознание этноса. Пока оно не изменится, не изменится и мировоззрение. Сколько тысячелетий, по крайней мере два с лишним, евреи кочуют по миру, и их самосознание не меняется! Самосознание этноса — это «нутро», обусловленное определенным образом жизни, поэтому при решении сложных политических задач всегда нужен системный подход.

Материалы исследования показали, что подавляющее большинство граждан республик СКФО соблюдают основные религиозные обряды. И религия оказывает свое влияние на различные сферы жизни общества. Часть взрослого населения в республиках СКФО считает себя принадлежащей к той или иной религиозной организации, хотя регулярно читающих Библию (Коран) насчитывается от 5,1 \% до 12,4 \%.

Существует сложившееся отношение к религии, обусловленное возрастом, полом, образованием и местом проживания. Обычно пожилые люди религиознее тех, кто относится к более молодым возрастным группам. Женщины, как правило, чаще вовлекаются в лоно религиозных организаций, чем мужчины, сельские жители активнее соблюдают религиозные обряды, чем горожане.

В целом посещаемость храмов и открытое выражение религиозных чувств чаще встречаются среди состоятельных людей, чем среди бедных групп населения, богатые не упускают возможности продемонстрировать свое отношение к религии публично: ремонтируют или строят новые храмы, передают им в дар ценные вещи.

Согласно материалам наших исследований, в мононациональных республиках СКФО значение ислама и посещаемость мечетей заметно растут.

Безработица в республиках Северного Кавказа подрывает традиционную гегемонию мужественности и разрушает существующие порядки.

Длительная безработица разрушила идеалы общественной жизни: роль мужчины -кормильца семьи деформируется, особенно из бедных республик СКФО РФ, меняется их социальный статус и для некоторых из них участие в религиозном течении ваххабизма является квазивозвратом мужественности.

C 80-х годов XX века на Северном Кавказе не был реализован ни один социальный проект, не открывались рабочие места. Экономический спад стал основой религиозного экстремизма.

Не удивительно, за короткий срок в обществе произошли большие перемены, и многие люди в поисках ответов обращаются к религиозной вере.
Вероятно, наиболее ярким примером этого феномена является распространение такого религиозного течения, как ваххабизм. В условиях радикальной трансформации, которую переживала в 1990-е гг. Россия в целом и северокавказский регион в частности, подрывались традиционные устои жизни социума, люди начинали искать объяснение происходящему и утешение в религии. Ваххабизм, делающий ставку на личную духовность, привлекает многих жителей Северного Кавказа, которых пугают негативные процессы, имеющие место в регионе. Религиозный фундаментализм на Северном Кавказе - результат социально-экономической и политической нестабильности. Ваххабитские лидеры призывают своих последователей строго следовать исламской системе принципов, верований, они призывают к буквальному пониманию таких терминов, как «реформаторство» или «обновление», и утверждают, что ваххабитское их прочтение должно применяться ко всем сферам общественной жизни и противостоять попыткам модернизации, предпринимаемым на Северном Кавказе.

Исламские фундаменталисты в Чечне основной задачей в борьбе с Российской армией считали создание «государства с единой нацией». Отвергая возможное сотрудничество с мусульманами и христианами - гражданами России, противники ваххабизма использовали (и используют) ради достижения своей цели экстремистские, террористические методы, которые затем переросли в крупномасштабные военные действия. То есть исламские фундаменталисты любой ценой хотят вернуть исламу его первоначальную чистоту и силу. А ислам, в свою очередь, отвечает на современные глобальные вызовы стремлением утвердить превосходство исламской культуры, исламских ценностей. Распространение этих идей среди населения республик СКФО имеет своей задачей убедить жителей региона в том, что основой политической и экономической жизни на Северном Кавказе должно стать шариатское государство. Цель идеологов исламского фундаментализма на Северном Кавказе заключается в исламизации всех сфер социальной и политической жизни республик СКФО РФ.

В обществе есть ожидание, что религиозный экстремизм может остановить только власть. Решение проблемы распространения ваххабизма на Северном Кавказе возможно только с применением силовых и административных методов. В обществе необходим диалог для выработки механизма снижения уровня социального напряжения, в процессе 


\section{Национальная безопасность $1(24) \cdot 2013$}

которого вырабатывались в рамках правового поля эффективные формы взаимодействия общества, тем самым минимизировать воздействие разрушающего фактора в социальном пространстве РФ. Большая роль в решении рассматриваемой проблемы принадлежит профессионалам в соответствующих областях. По крайней мере, общество должно понимать, что государство создает для этого условия.

В итоге материалы исследования показали, что в мононациональных республиках СКФО значение ислама и посещаемость мечетей заметно растут. Появление религиозного, идейно-политического течения ваххабизм, делающего ставку на личную духовность, привлекает многих жителей Северного Кавказа, потому что их пугают негативные процессы, которые происходят в регионе.

\section{Библиография:}

1. Адорно Т. Исследование авторитарной личности. M., 2001;

2. Аликберов А.К. Эпоха классического ислама на Кавказе. М., 2003;

3. Андреева Л.А. «Местник Божий» на царском троне: Христианская цивилизационная модель сакрализации власти в российской истории. М., 2002;

4. Асадуллин Ф.А. Ислам в Москве. М., 2007;

5. Бауман 3. Индивидуализированное общество. M., 2002.

6. Гудков Л.Д. Негативная идентичность. М., 2004;

7. Дзеранов Т.Е. Религия осетин и русская культура. Владикавказ, 2006;

8. Дзуцев Х.В. Беслан после 1-3 сентября 2004 г.: социологический анализ. М., 2008;

9. Дробижева Л.М. Возможность совместимости гражданской и этнической идентичности// Национально-гражданские идентичности и толерантность. Опыт России и Украины в период трансформаций. Киев, 2007;

10. Иванов В.Н. Россия федеративная: кризис и пути его преодоления. М., 1999;
11. Карпов А.В. Язычество, христианство, двоеверие. Религиозная жизнь Древней Руси в IX-XI вв. СПб., 2008;

12. Малашенко А.В. Ислам для России. М., 2007;

13. Путин В.В. Послание Федеральному Собранию Российской Федерации, 12 декабря 2012г. // www.kremlin.ru;

14. Федотова В.Г. Хорошее общество. М., 2005;

\section{References (transliteration):}

1. Adorno T. Issledovanie avtoritarnoy lichnosti. M., 2001;

2. Alikberov A.K. Epokha klassicheskogo islama na Kavkaze. M., 2003;

3. Andreeva L.A. «Mestnik Bozhiy» na tsarskom trone: Khristianskaya tsivilizatsionnaya model' sakralizatsii vlasti v rossiyskoy istorii. M., 2002;

4. Asadullin F.A. Islam v Moskve. M., 2007;

5. Bauman Z. Individualizirovannoe obshchestvo. M., 2002.

6. Gudkov L.D. Negativnaya identichnost'. M., 2004;

7. Dzeranov T.E. Religiya osetin i russkaya kul'tura. Vladikavkaz, 2006;

8. Dzutsev Kh.V. Beslan posle 1-3 sentyabrya 2004 g.: sotsiologicheskiy analiz. M., 2008;

9. Drobizheva L.M. Vozmozhnost' sovmestimosti grazhdanskoy i etnicheskoy identichnosti// Natsional'no-grazhdanskie identichnosti i tolerantnost'. Opyt Rossii i Ukrainy v period transformatsiy. Kiev, 2007;

10. Ivanov V.N. Rossiya federativnaya: krizis i puti ego preodoleniya. M., 1999;

11. Karpov A.V. Yazychestvo, khristianstvo, dvoeverie. Religioznaya zhizn' Drevney Rusi v IX-XI vv. SPb., 2008;

12. Malashenko A.V. Islam dlya Rossii. M., 2007;

13. Putin V.V. Poslanie Federal'nomu Sobraniyu Rossiyskoy Federatsii, 12 dekabrya 2012g. // www.kremlin.ru;

14. Fedotova V.G. Khoroshee obshchestvo. M., 2005; 